\title{
Rafael Lerma's Photojournalistic Take on the Duterte Administration's Drug War: A Counter-Barthesian Semiological Study
}

\author{
Feorillo A. Demeterio III
}

Rafael Lerma is an award-winning and outspoken Filipino photojournalist who works for the broadsheet The Philippine Daily Inquirer. When President Rodrigo Duterte took office on 01 July 2016 and started to implement his campaign promise to mount a thorough war on drugs, Lerma became one of the photojournalists who consistently documented the grisly track of the said war. His most iconic imagethat of a dead pedicab driver being cradled by his grief-stricken widow-did not escape the rambling speech of the President himself during the latter's first State of the Nation Address. This paper culls 25 of Lerma's most famous images related to the Duterte administration's drug war. From these 25 images, six recurrent sociocultural icons have been identified: 1 ) poverty; 2 ) the dehumanization/demonization of the casualties; 3) religion; 4) the weakness of governance in the Philippines; 5) Operation Plan Tokhang conducted by the Philippine National Police; and 6) the state and the nation. By subjecting these visual sociocultural icons to an inverted version of the semiology of the early phase of the French philosopher and cultural critic Roland Barthes, the researcher textually explores Lerma's take on the said war. Furthermore, this paper theoretically tests the capacity of Barthes' semiology to tackle not only ideological discourses that are tucked beneath some sociocultural icons but more so counterideological discourses that are launched by the less privileged sectors of society.

Keywords: dominant adaptation discourse, De-Westernization of film adaptation discourse, film adaptation theory, contextualization of theory, indigenous, vernacular and hybrid theory

When Rodrigo Duterte, the sixteenth President of the Republic of the Philippines, launched his promised all-out drug war as soon as he took office on 30 June 2016, a number of Filipino photojournalists documented the grisly aftermaths of the daily killings. Among these photojournalists were Agence France-Presse's Noel Celis; Union of Catholic Asian News Hong Kong's Vincent Go; The Philippine Daily Inquirer's Rafael Lerma; Reuter's Czar Dancel and Dondi Tawatao; and freelancers Ezra Acayan, Alyx Arumpac, Jes Aznar, Kimberly dela Cruz, Dante Dionisia, Linus Escandor, Jay Ganzon, Carlo Gabuco, Eloisa Lopez, Hannah Reyes Morales, Alecs Ongcal, and Basilio Sepe. One of the most ardent and outspoken among them was Lerma, more popularly known as Raffy Lerma. Without sidelining the contributions and significance of the other photojournalists, this paper opted to focus on the corpus of images generated by Lerma on the Duterte administration's drug war.

Lerma, a graduate of the University of the Philippines Diliman and the Ateneo De Manila University, is a 39-year-old photojournalist who has been 
working with the broadsheet The Philippine Daily Inquirer (PDI) for the past decade. He is a recipient of recognitions from the Catholic Mass Media Awards, the La Sallian Scholarum Awards, the Save the Children Media Awards, and the Center for Media Freedom and Responsibility. His most iconic image - that of a dead pedicab driver being cradled by his live-in partner-did not escape the rambling speech of the President himself during the latter's first State of the Nation Address on 25 July 2016. On 04 December 2016, Lerma and his dedication to his unglamorous and dangerous work of documenting the said drug war were featured by the British Broadcasting Corporation (BBC) in the video documentary "Duterte Drug War: Manila's Brutal Nightshift" (Brownstone, 2016). On 27 March 2017, he and his works were featured again by the New York Times in another video documentary When a President Says, 'I'll Kill You' (Glazer \& Rocklin, 2017).

Using an inverted version of the semiology of the early phase of the French philosopher and cultural critic Roland Barthes (1915-1980), this paper analyzes some of Lerma's representative images on the said drug war in order to textually explore his visual take on the said crackdown. At the time of this paper's writing, about six thousand individuals have already died, directly or indirectly, in connection with the said drug war (Regencia \& Ali, 2016). About four thousand of the total deaths are considered extrajudicial killings involving unknown assailants, while about two thousand are from police operations (Regencia \& Ali 2016). Results of the December 2016 survey conducted by the Philippine polling organization Social Weather Stations ("Fourth quarter 2016 Social Weather Survey: 78\% of Pinoys worry about becoming victims of EJK; $94 \%$ say it is important that drug suspects be captured alive," 2016) showed that 78\% of the Filipinos are worried that they or somebody close to them will become the next casualty in the drug war. Paradoxically, the same survey also showed that $85 \%$ of the Filipinos are satisfied with how the Duterte administration is conducting its campaign against illegal substances. Lerma himself stated in the $\mathrm{BBC}$ video documentary that he is "for the drug war, but not the killings" (Brownstone, 2016).

\section{The $\mathbf{2 5}$ Selected Images of Lerma}

Lerma had already taken hundreds, if not thousands, of images on the drug war of the Duterte administration. To make this semiological study possible, a manageable number of his most representative images had to be isolated. This was done with the help of the image section of the Google search engine. On 12 December 2016, the researcher keyed in the phrase "Raffy Lerma Drugs" into the said section. From the 400 images that appeared on screen, the first 25 images that actually belong to Lerma and are part of 
PDI's online publication were isolated. It has to be noted that results coming from Google's search engine are arranged in a hierarchy of importance and relevance based on a trade secret algorithm that is in turn based on a trade secret set of factors. But experts in the field of search engine optimization have identified click-through, bounce, and dwelling time rates as some of the leading factors that affect this hierarchy, and they are more directly shaped by users, instead of website creators and designers (Southern 2016). Since the selection process of Lerma's photographs was already delimited to those coming from PDI's online publication that is supposedly manned by more or less the same website and webpage creators and designers, this paper can deemphasize the factors that are more directly shaped by these technical people. Thus, the 25 photographs selected could be assumed to have had more exposure to more Internet users than the rest, at least during the period the image search was done. This paper, therefore, considered the following 25 images, labelled with their respective titles, sources, and dates of publication, as the most representative documents taken by Lerma on the ongoing drug war:

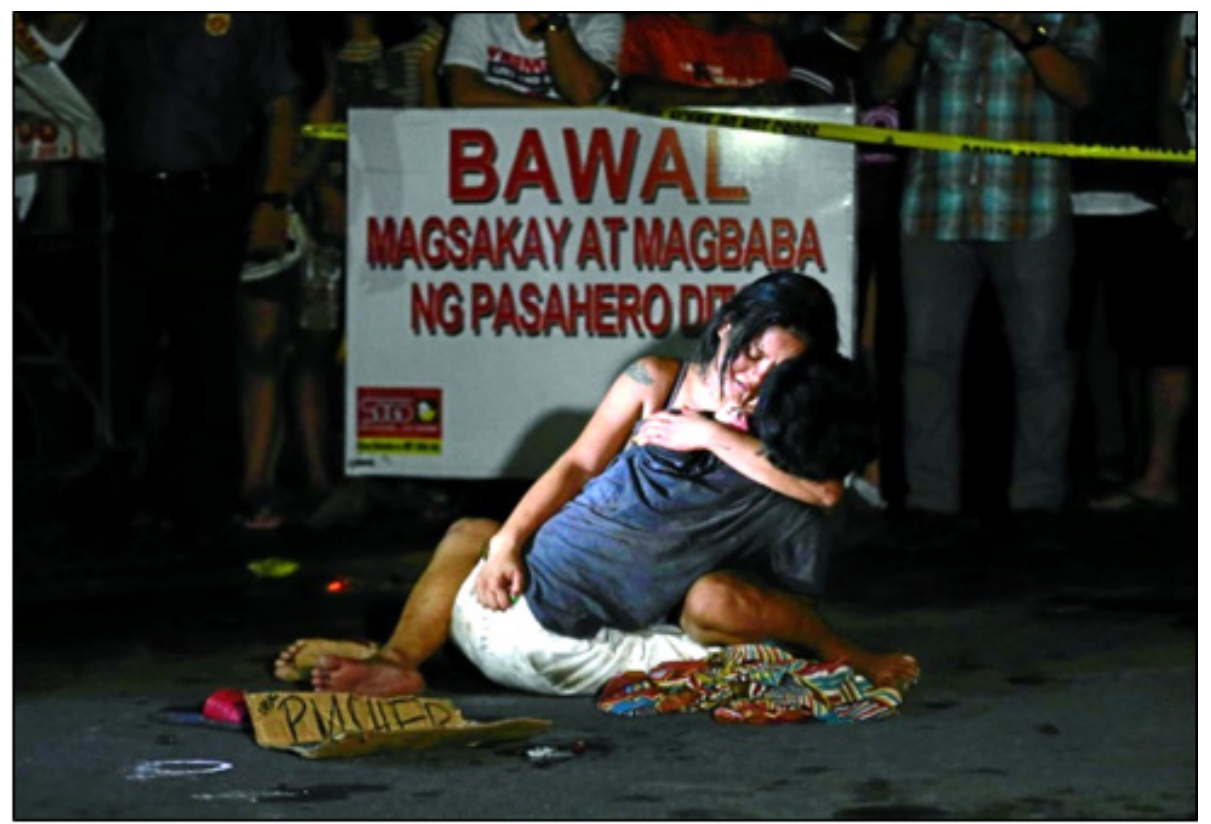

Figure 1: "Lamentation." Philippine Daily Inquirer, 04 July 2016. Retrieved from http:// newsinfo.inquirer.net/798551/church-thou-shall-not-kill. Copyright 2016 by Philippine Daily Inquirer. 


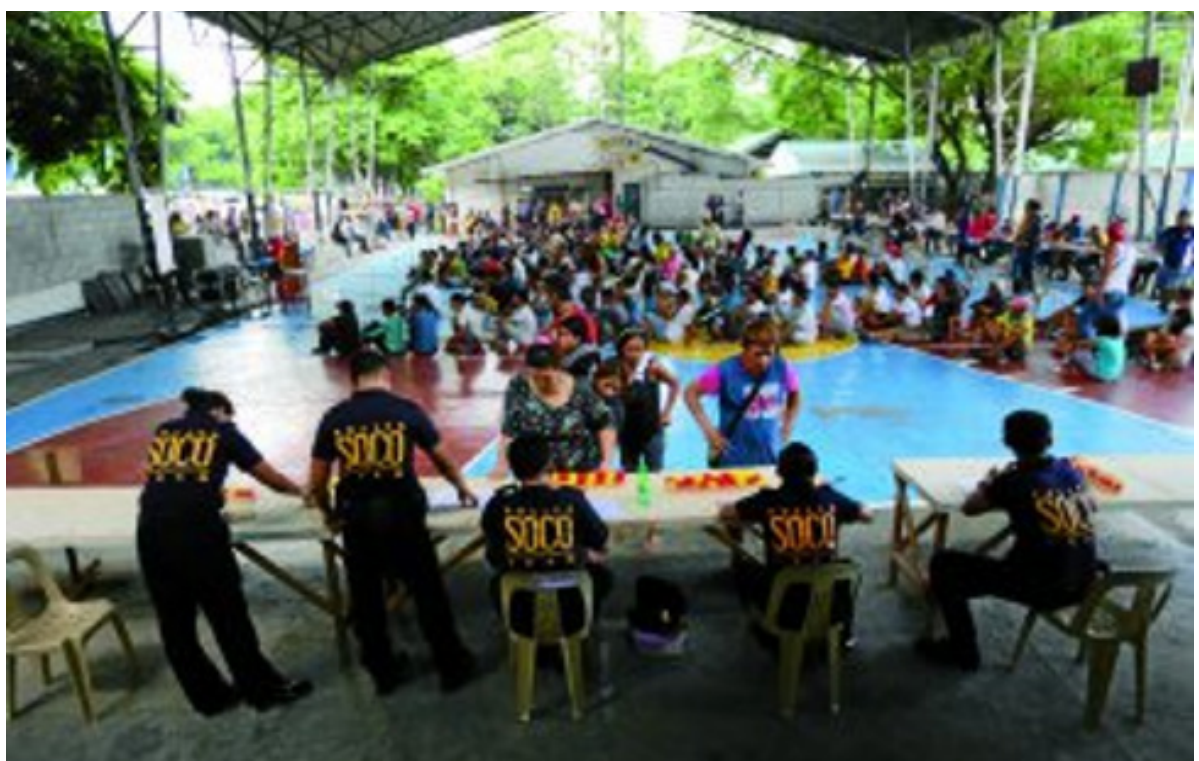

Figure 2. "Drug Users in Many Parts of the Country Have Surrendered to Rehabilitation," Philippine Daily Inquirer, 06 July 2016. Retrieved from http://newsinfo.inquirer.net/794564/98drug-pushing-suspects-users-surrender-to-lanao-norte-town-cops. Copyright 2016 by Philippine Daily Inquirer.

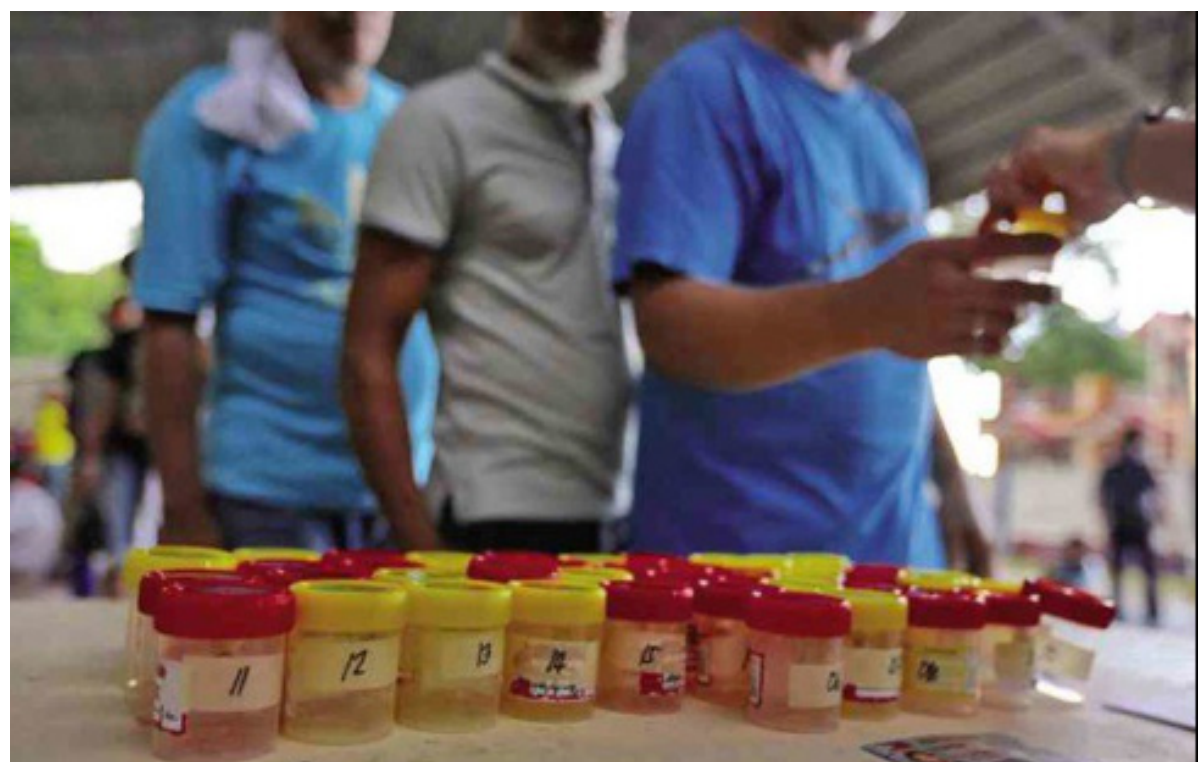

Figure 3. "Confessed Users Undergo a Drug Test in Camp Karingal." Philippine Daily Inquirer, 07 July 2016. Retrieved from http://newsinfo.inquirer.net/797445/300-qc-barangay-officerstest-positive-for-drugs. Copyright 2016 by Philippine Daily Inquirer. 


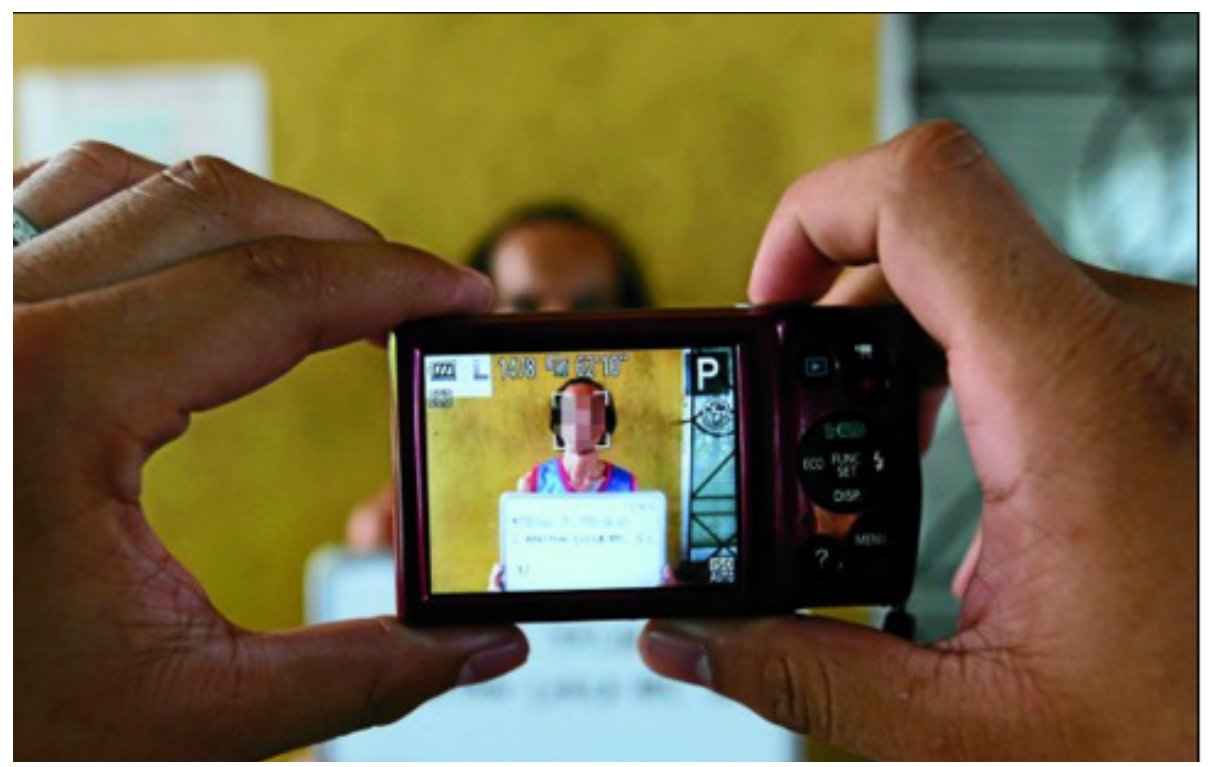

Figure 4. "A Drug Dependent's Mug Shot is Taken," Philippine Daily Inquirer, 14 July 2016. Retrieved from http://newsinfo.inquirer.net/797445/300-qc-barangay-officers-test-positivefor-drugs. Copyright 2016 by Philippine Daily Inquirer.

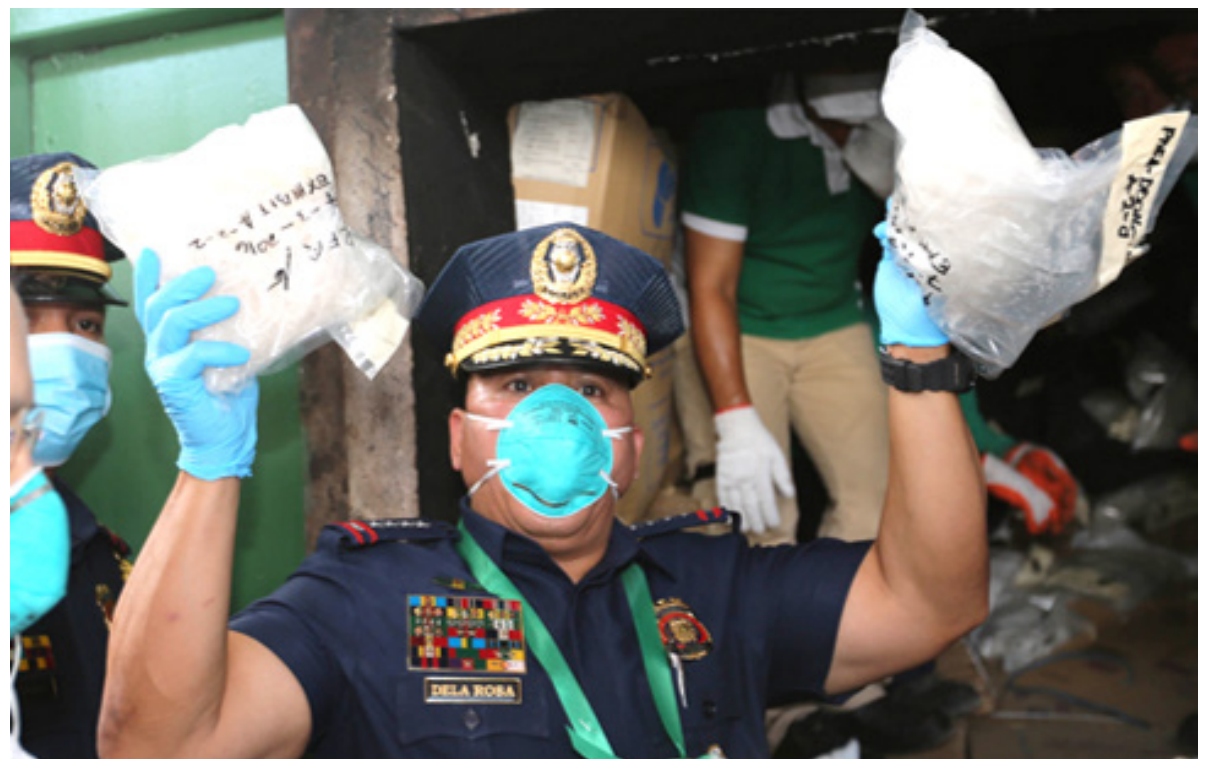

Figure 5. "Bato Destroys 'Bato',' Philippine Daily Inquirer, 14 July 2016. Retrieved from http:// newsinfo.inquirer.net/796011/drug-lords-ordered-hits. Copyright 2016 by Philippine Daily Inquirer. 


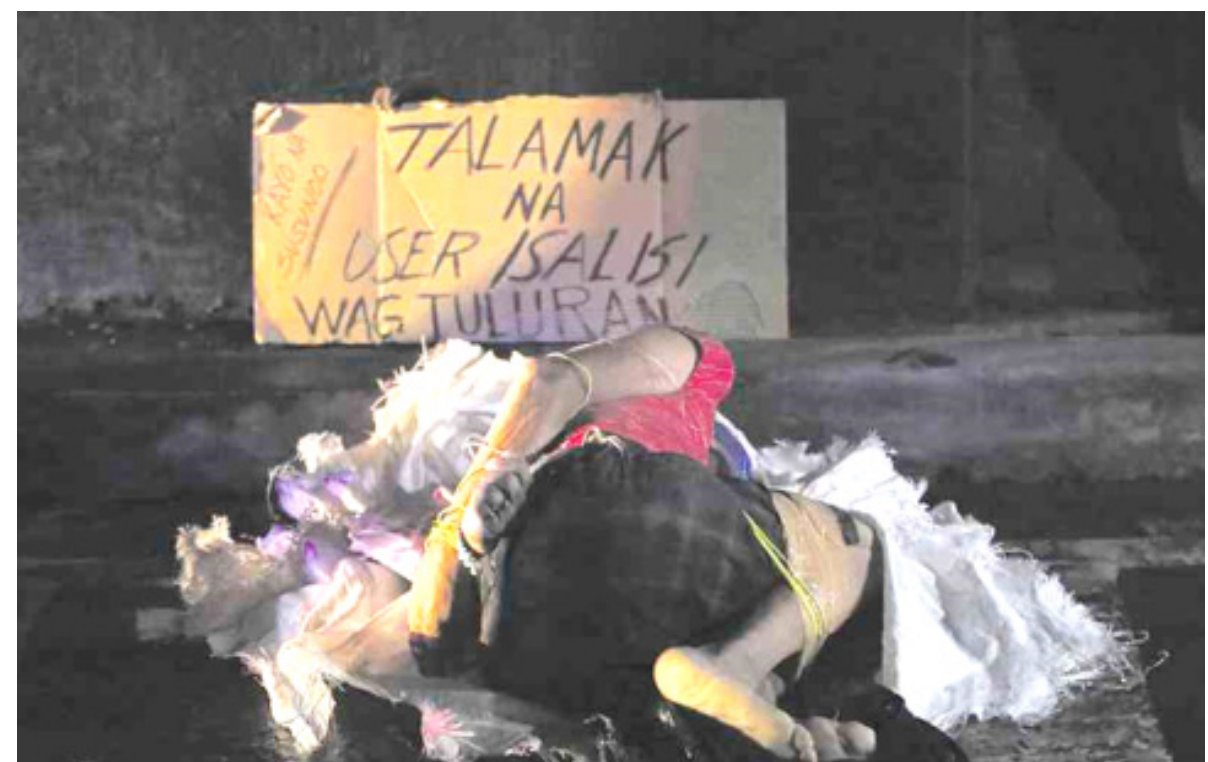

Figure 6. "Pray You Don't See this on Your Street," News Information/Headlines, Philippine Daily Inquirer, 20 July 2016. Retrieved from http://newsinfo.inquirer.net/797360/mpdchurns-out-usual-shootout-gun-grabbing-tales-kills-7-more. Copyright 2016 by Philippine Daily Inquirer.

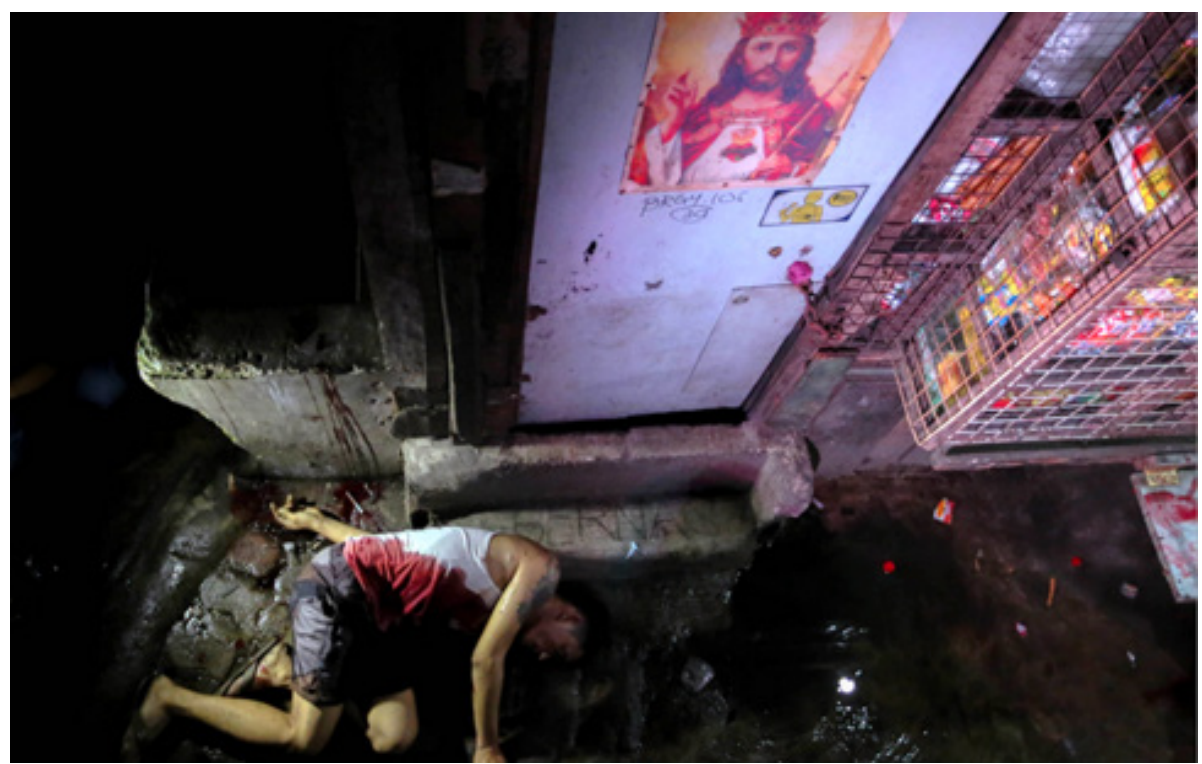

Figure 7. "Policeman Killed," Frame, Philippine Daily Inquirer, 21 July 2016. Retrieved from http://newsinfo.inquirer.net/802212/6-killed-by-cops-in-bulacan-drug-buy-busts. Copyright 2016 by Philippine Daily Inquirer. 


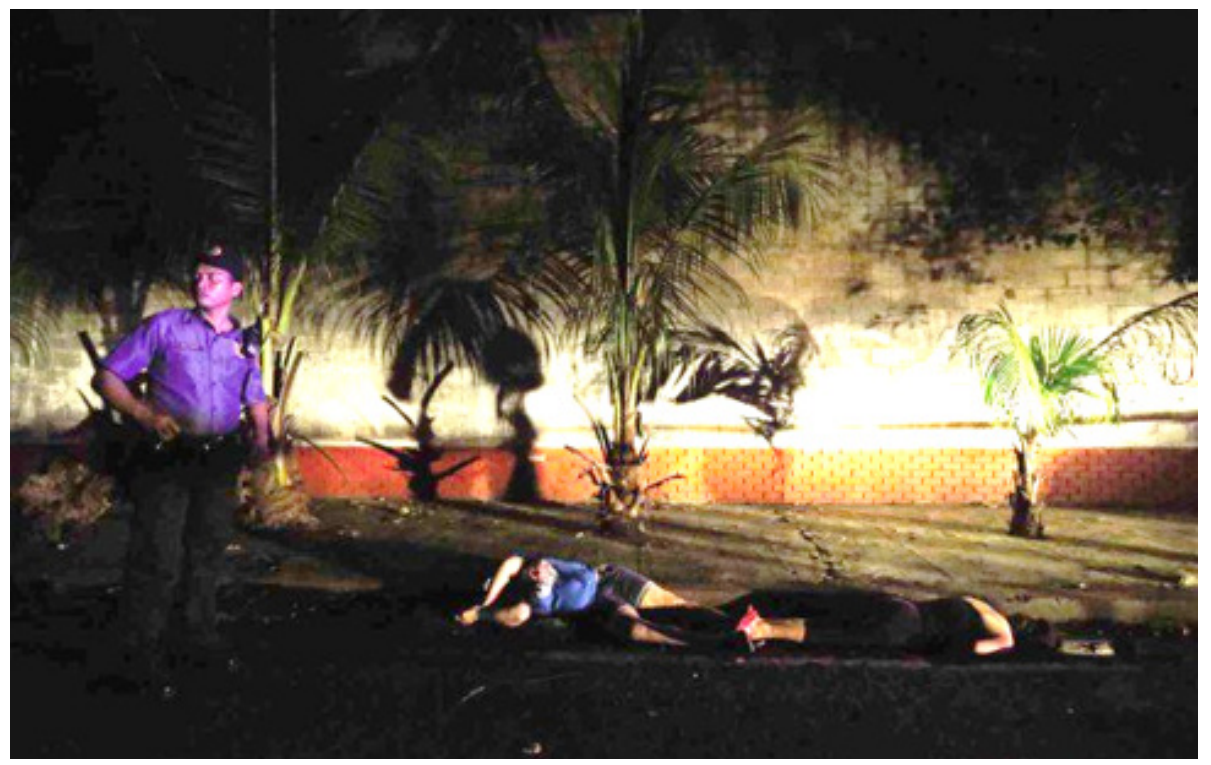

Figure 8. "Salvage Victims," News Information/ Headlines, Philippine Daily Inquirer, 22 July 2016. Retrieved from http://newsinfo.inquirer.net/798060/5-more-drug-war-deaths-in-12hrs. Copyright 2016 by Philippine Daily Inquirer.

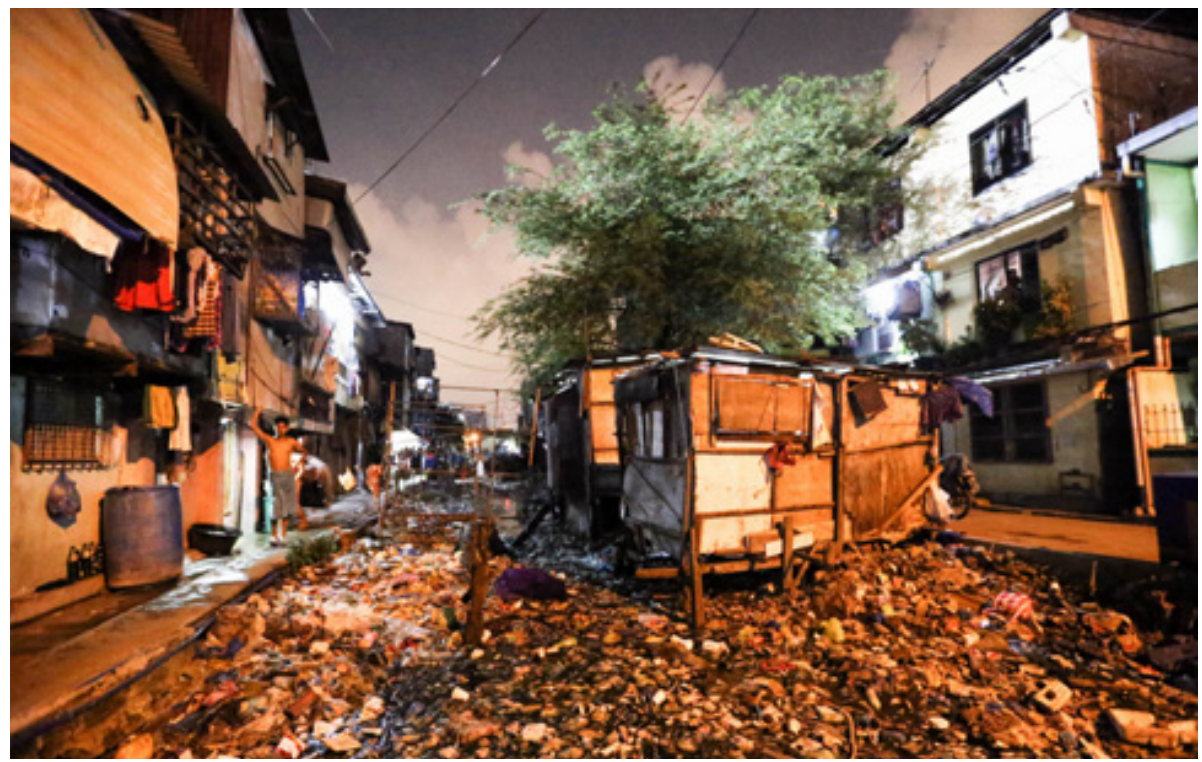

Figure 9. “Dark Side of Drug War," Frame, Philippine Daily Inquirer, 30 July 2016. Retrieved from http://newsinfo.inquirer.net/801509/widow-tells-duterte-kill-drugs-not-people. Copyright 2016 by Philippine Daily Inquirer. 


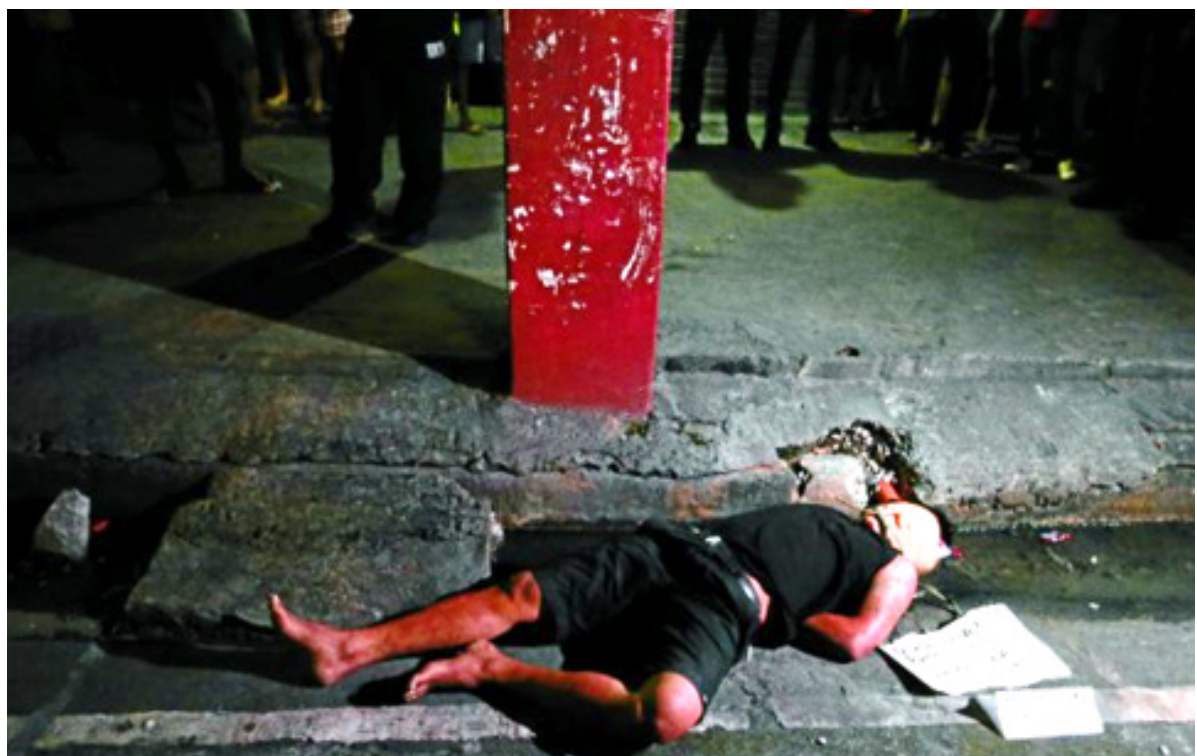

Figure 10. "The Body of an Alleged Drug Pusher and Robber," News Information/Featured Gallery, Philippine Daily Inquirer, 06 August 2016. Retrieved from http://newsinfo.inquirer. net/803494/deads-kin-offered-psychiatric-help. Copyright 2016 by Philippine Daily Inquirer.

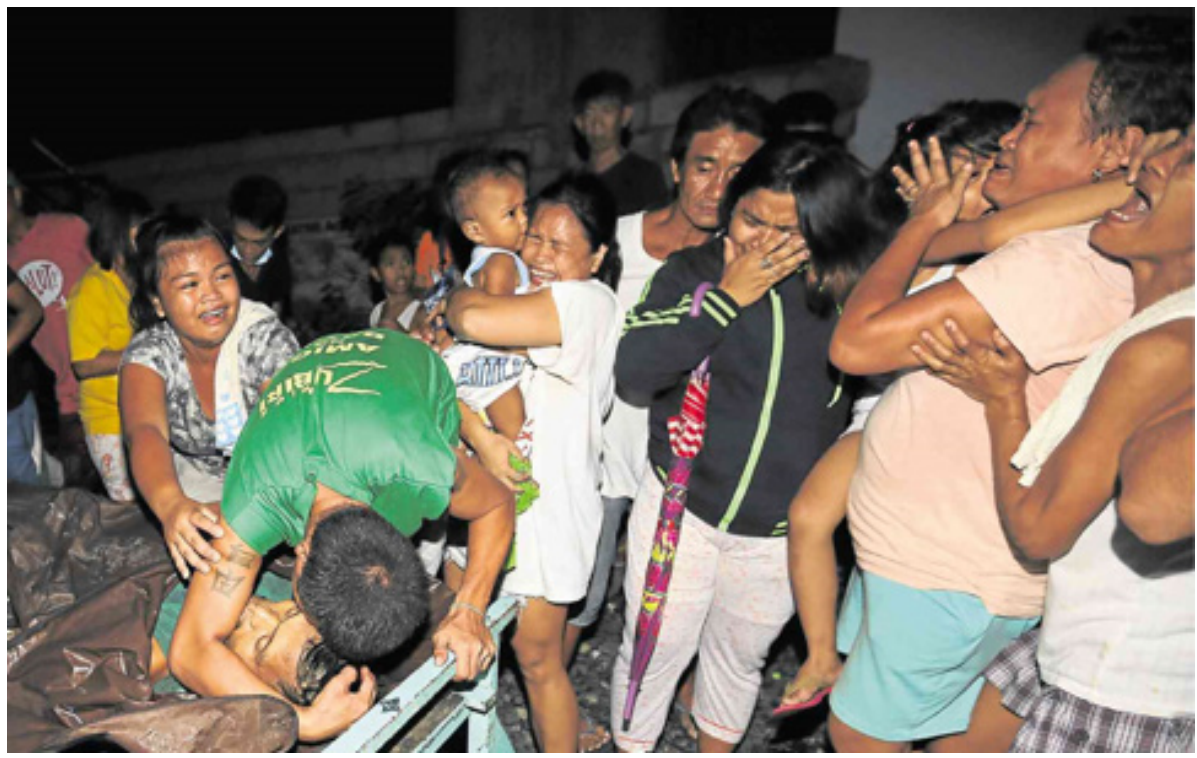

Figure 11. "Family in Anguish," News Information/Metro Manila, Philippine Daily Inquirer, 19 August 2016. Retrieved from http://newsinfo.inquirer.net/807669/killings-go-on-as-senateprobes-digong-drug-war. Copyright 2016 by Philippine Daily Inquirer. 


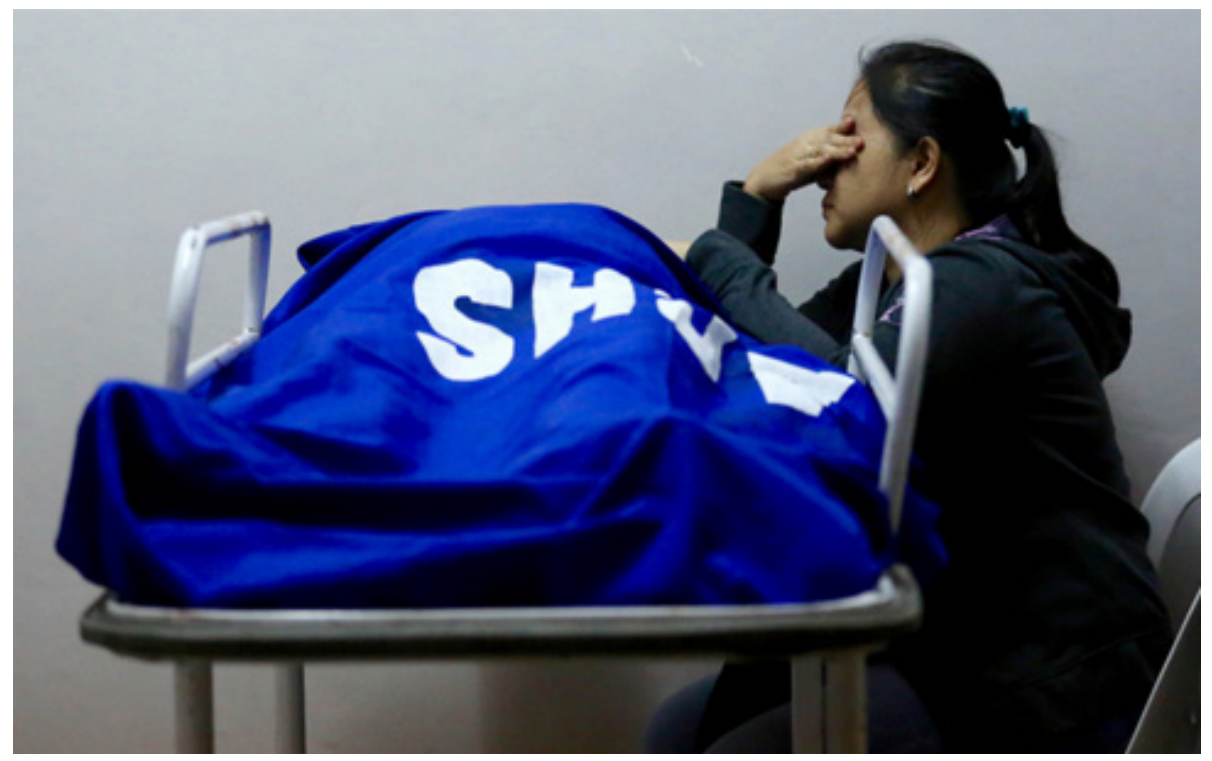

Figure 12. "Cop Killed in Buy-Bust Operation," Frame, Philippine Daily Inquirer, 20 August 2016. Retrieved from http://frame.inquirer.net/2752/cop-killed-in-buy-bust-operation/. Copyright 2016 by Philippine Daily Inquirer.

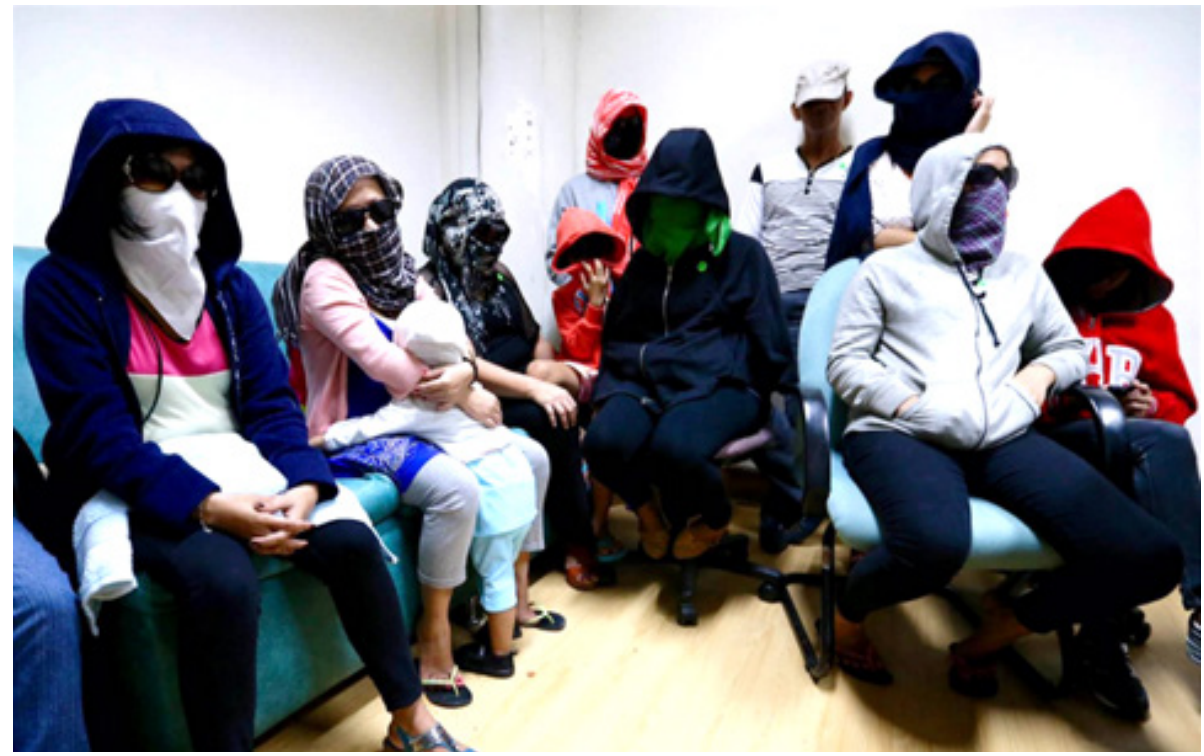

Figure 13. "Waiting to Testify," Frame, Philippine Daily Inquirer, 23 August 2016. Retrieved from http://frame.inquirer.net/2761/waiting-to-testify/. Copyright 2016 by Philippine Daily Inquirer. 


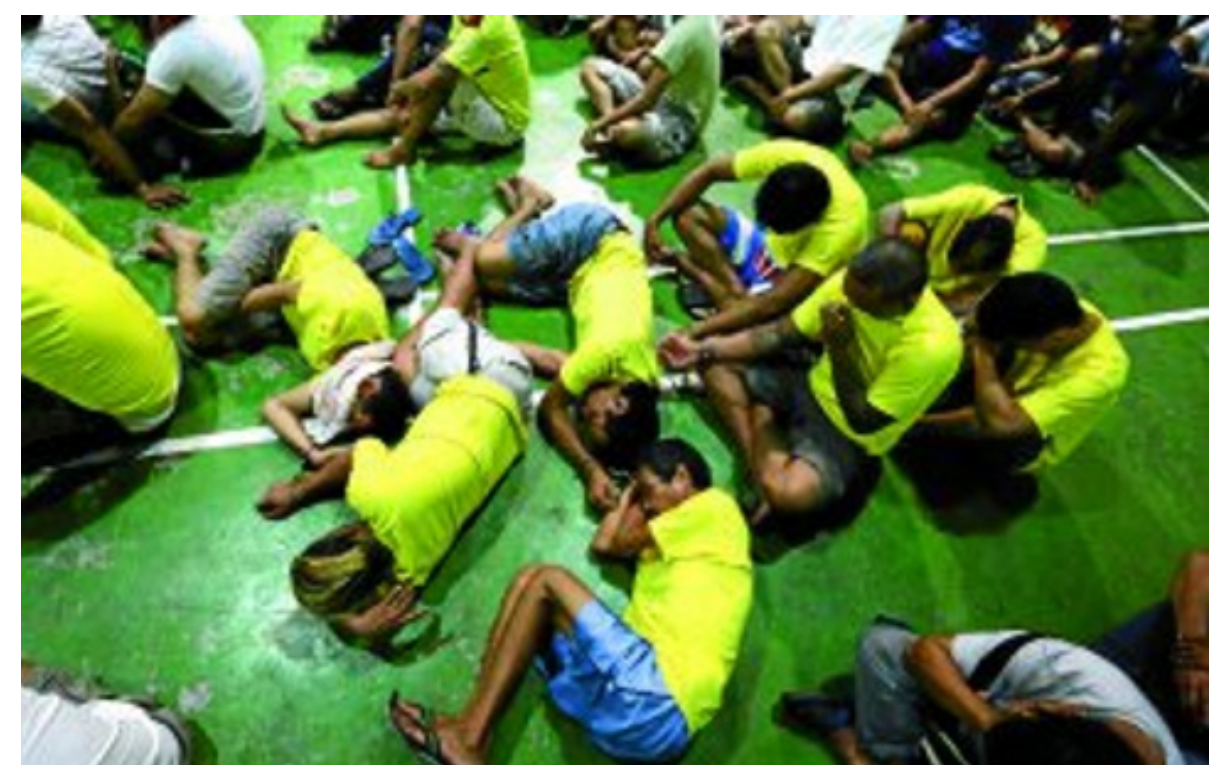

Figure 14. "Arrested Drug Suspects," News Information/Regions, Philippine Daily Inquirer, 06 September 2016. Retrieved from http://newsinfo.inquirer.net/813384/3-killed-15-nabbedin-anti-drug-raid-in-pampanga-city. Copyright 2016 by Philippine Daily Inquirer.

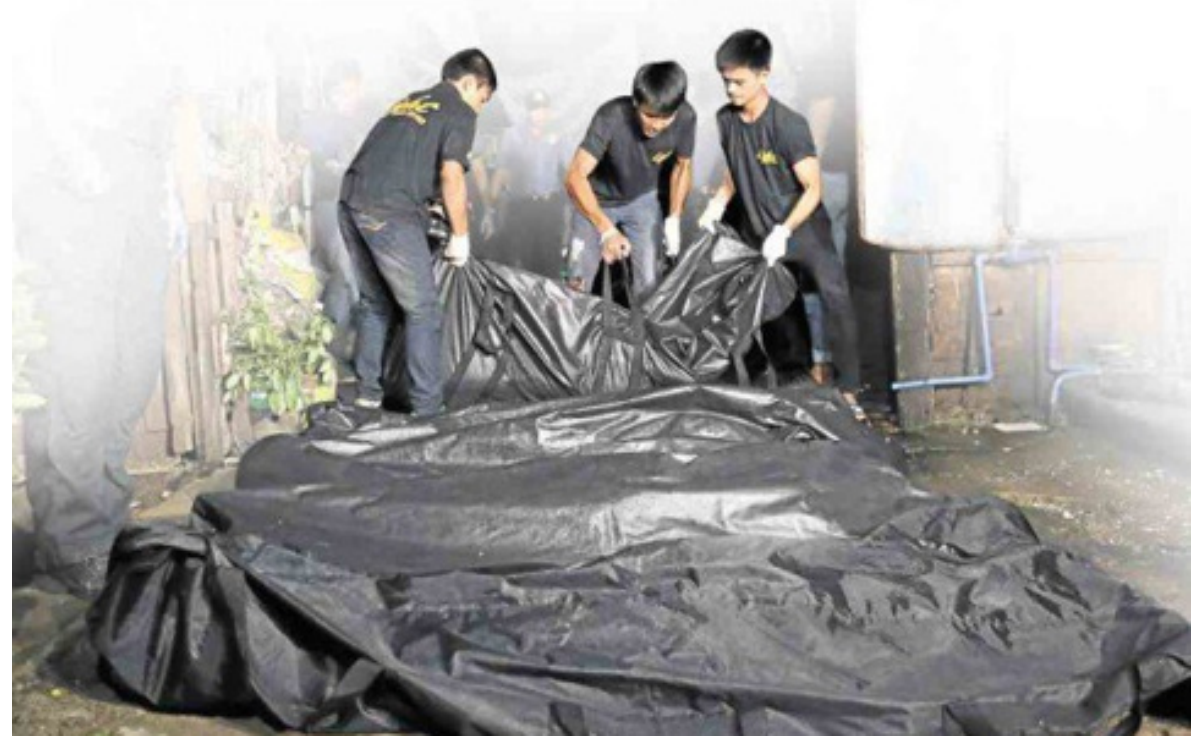

Figure 15. "Latest Four to Fall," Headlines, Philippine Daily Inquirer, 10 September 2016. Retrieved from http://newsinfo.inquirer.net/814293/qcpds-kills-hit-72-in-du30-drug-war. Copyright 2016 by Philippine Daily Inquirer. 


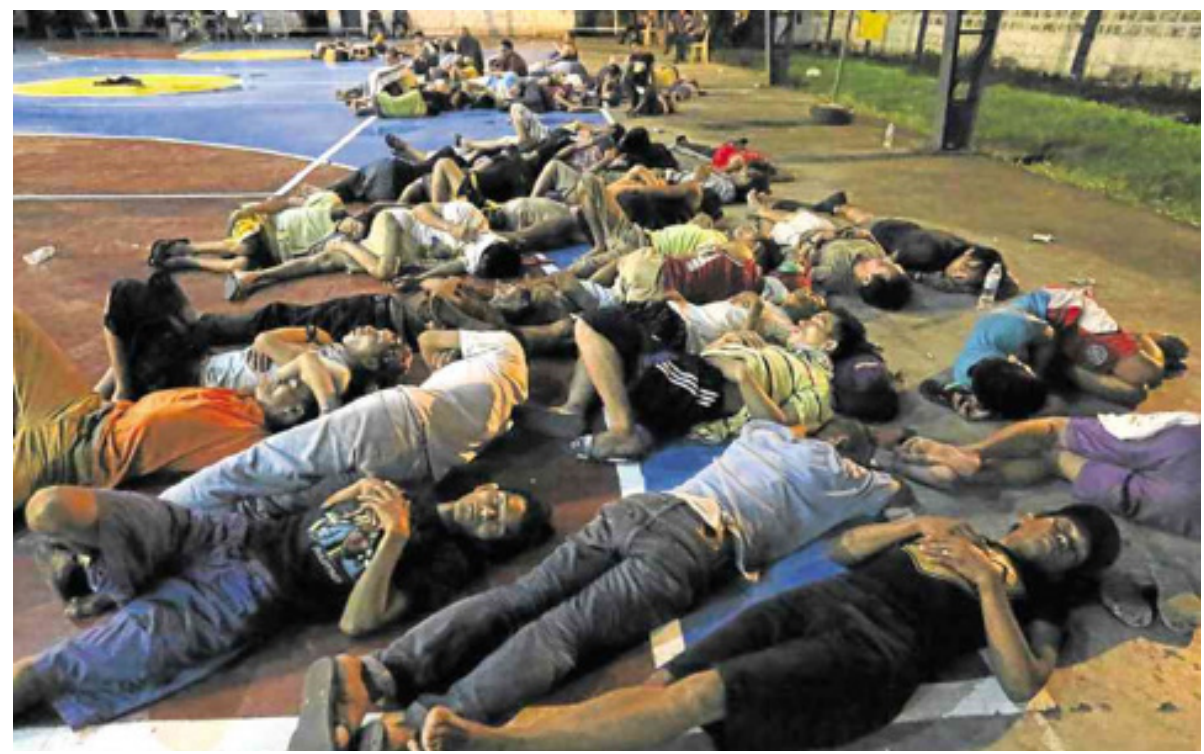

Figure 16. "Drug Suspects Arrested in Two Raids," News Information/Headlines, Philippine Daily Inquirer, 18 September 2016. retrieved from http://newsinfo.inquirer.net/816264/145suspects-nabbed-in-culiat-raids. Copyright 2016 by Philippine Daily Inquirer.

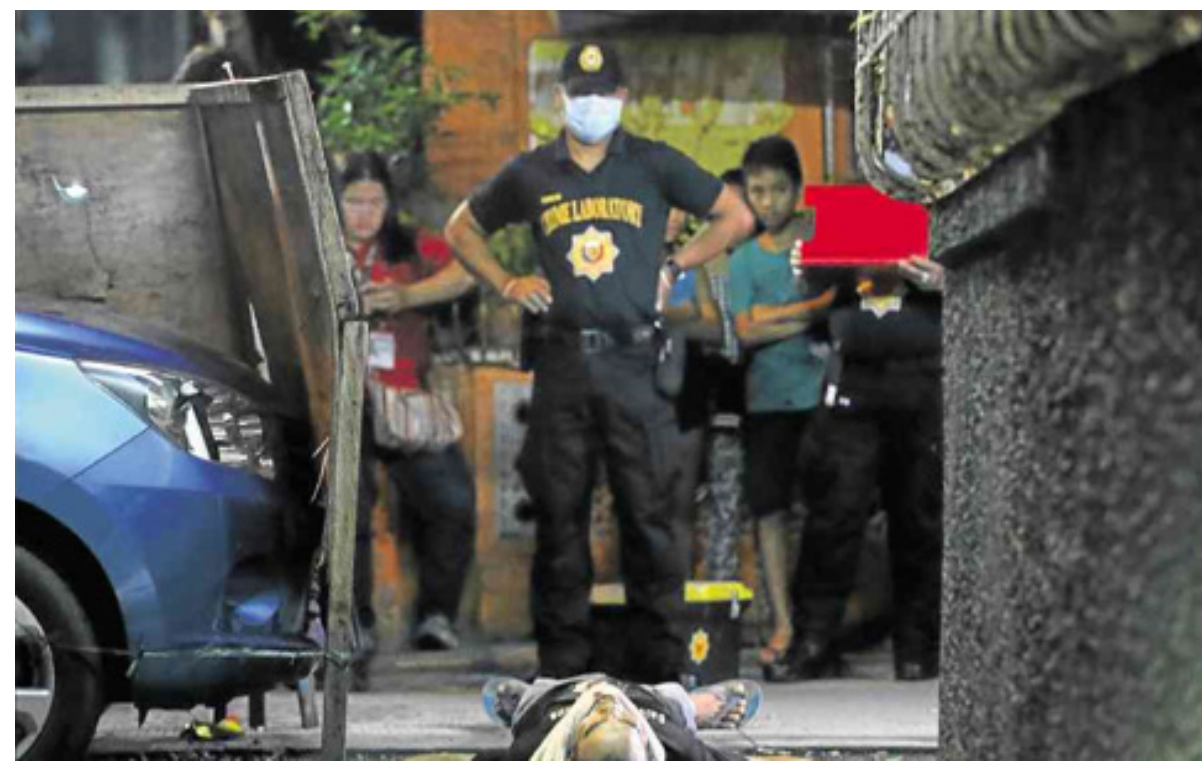

Figure 17. "Nunoy (Coloma) was Gunned Down by Still Unidentified Persons," News Information/ Headlines, Philippine Daily Inquirer, 26 September 2016. Retrieved from http:// newsinfo.inquirer.net/818898/103-killed-so-far-in-qcpd-war-on-drugs. Copyright 2016 by Philippine Daily Inquirer. 


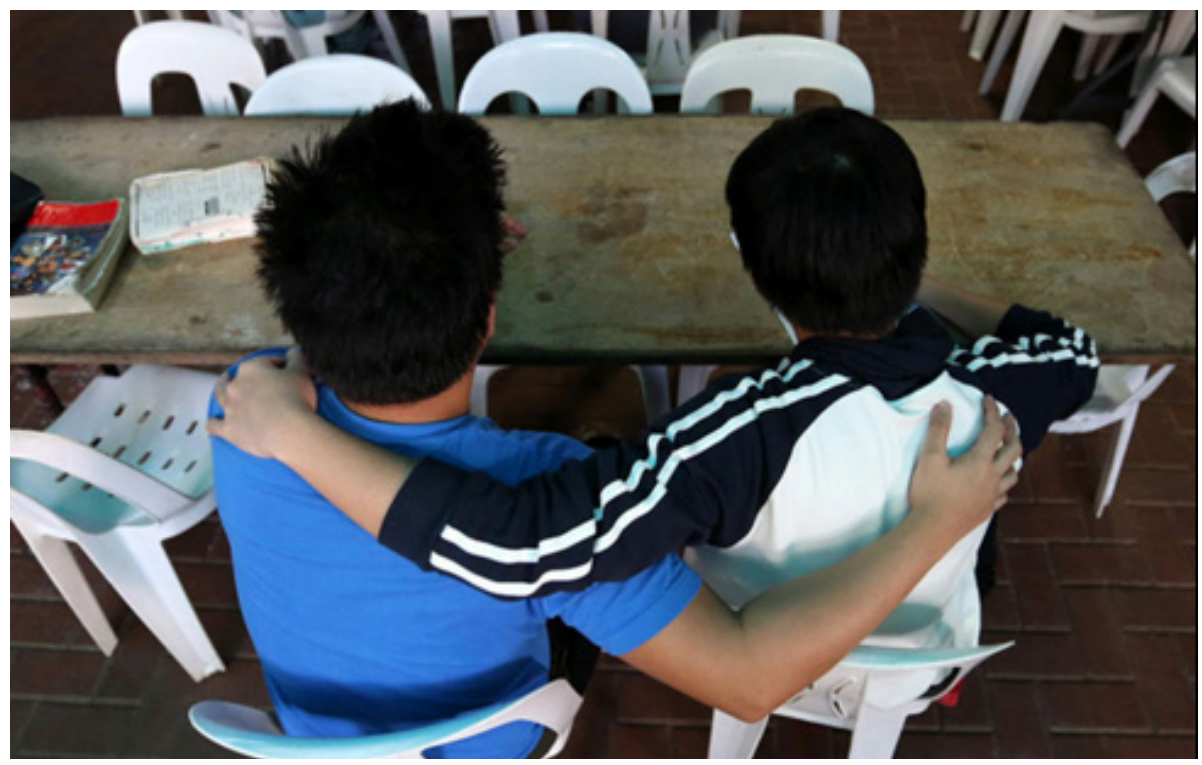

Figure 18. "After a Small Fight. .. these Men are Made to Stick Together," Special Feature, Philippine Daily Inquirer, 08 October 2016. Retrieved from http://www.inquirer.net/duterte/ drug-rehab-3. Copyright 2016 by Philippine Daily Inquirer. same URL?

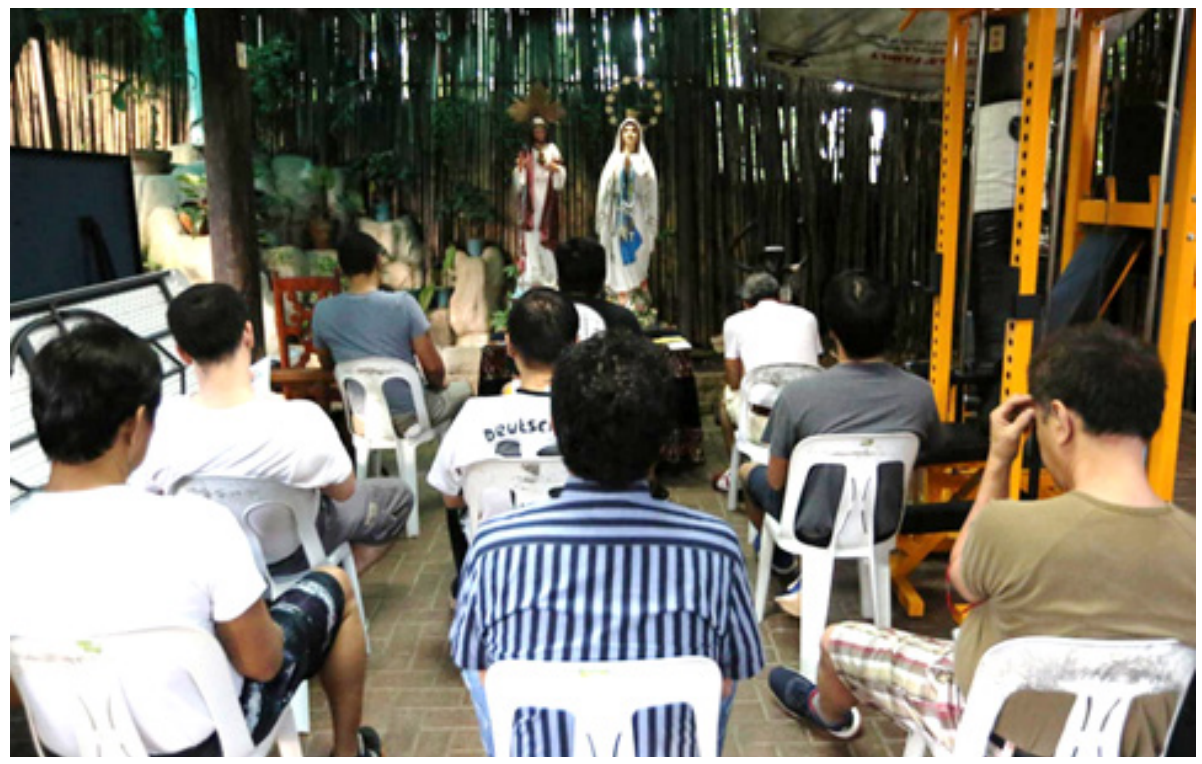

Figure 19. "At the Mess Hall, an Altar with Religious Figures Watch over Patients," Special Feature, Philippine Daily Inquirer, 08 October 2016. Retrieved from http://www.inquirer.net/ duterte/drug-rehab-3 Copyright 2016 by Philippine Daily Inquirer. same URL? 


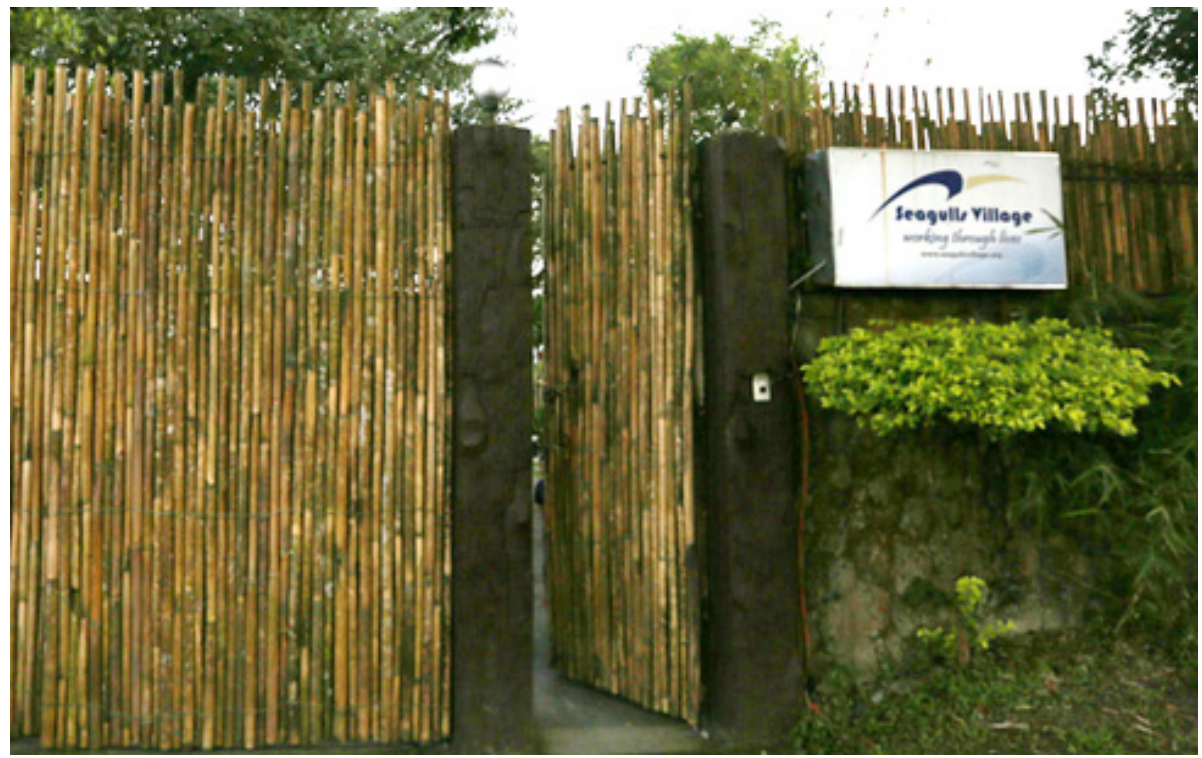

Figure 20. "Seagulls in Tagaytay City Caters mostly to Patients who can Afford to Pay," Special Feature, Philippine Daily Inquirer, 08 October 2016. Retrieved from http://www.inquirer.net/ duterte/drug-rehab-3. Copyright 2016 by Philippine Daily Inquirer. same URL?

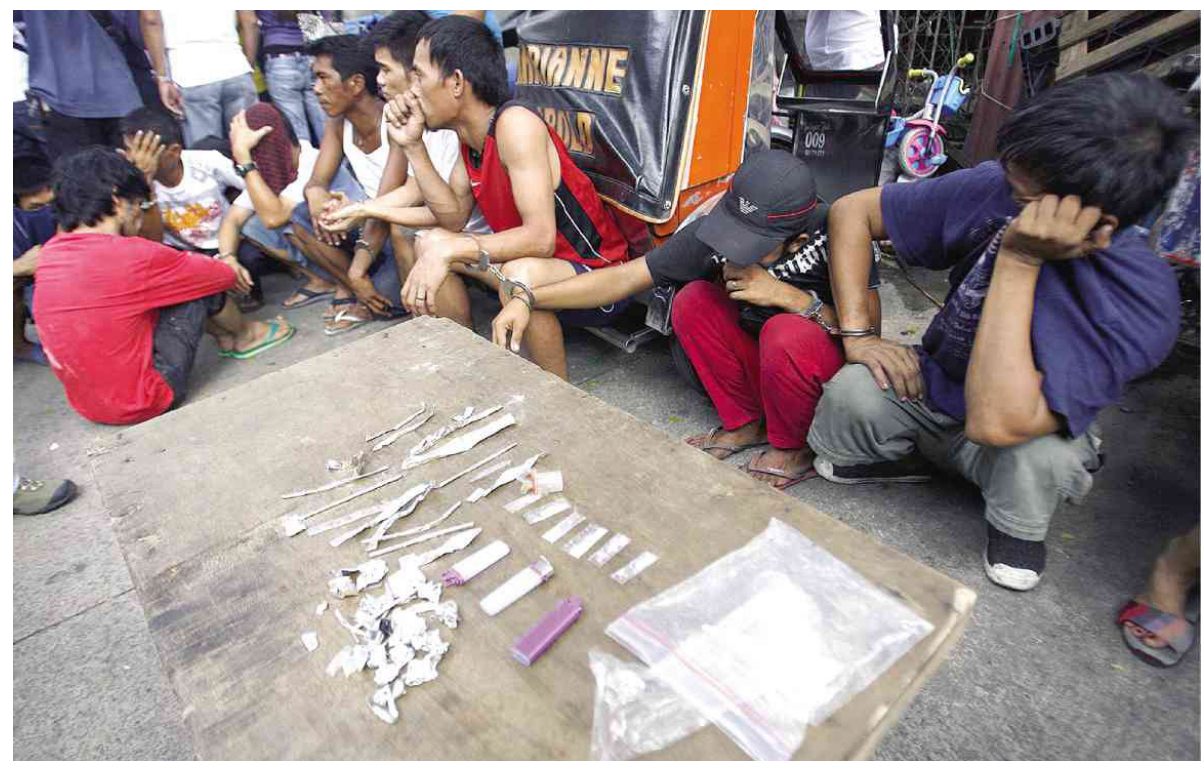

Figure 21."Drug Den Raid in Quezon City," News Information/Metro Manila, Philippine Daily Inquirer, 24 October 2016. Retrieved from http://newsinfo.inquirer.net/830232/drug-suspectwith-grenade-killed-in-qc-police-raid. Copyright 2016 by Philippine Daily Inquirer. 


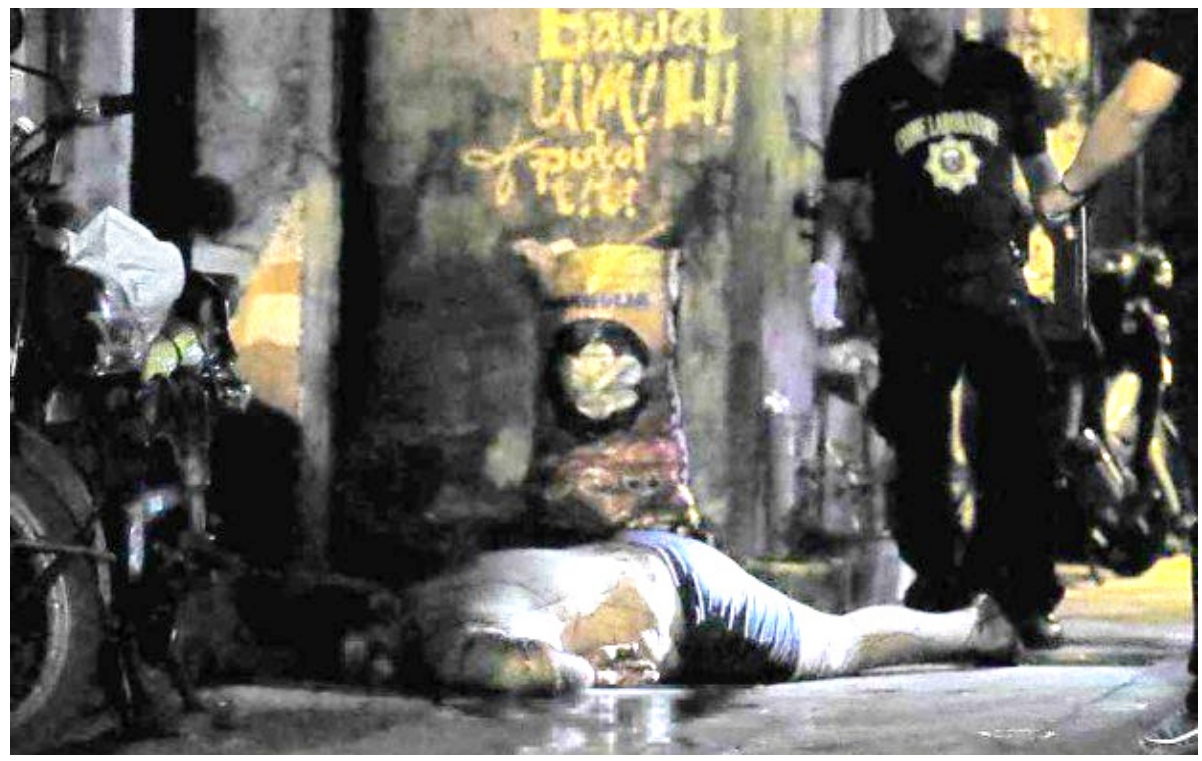

Figure 22. "Ranilo Maydan, Jr.'s Bullet-Riddled Body Lies in Front of his House," News Information/Headlines, Philippine Daily Inquirer, 24 October 2016. Retrieved from http:// newsinfo.inquirer.net/830207/never-give-your-killers-peace Copyright 2016 by Philippine Daily Inquirer.

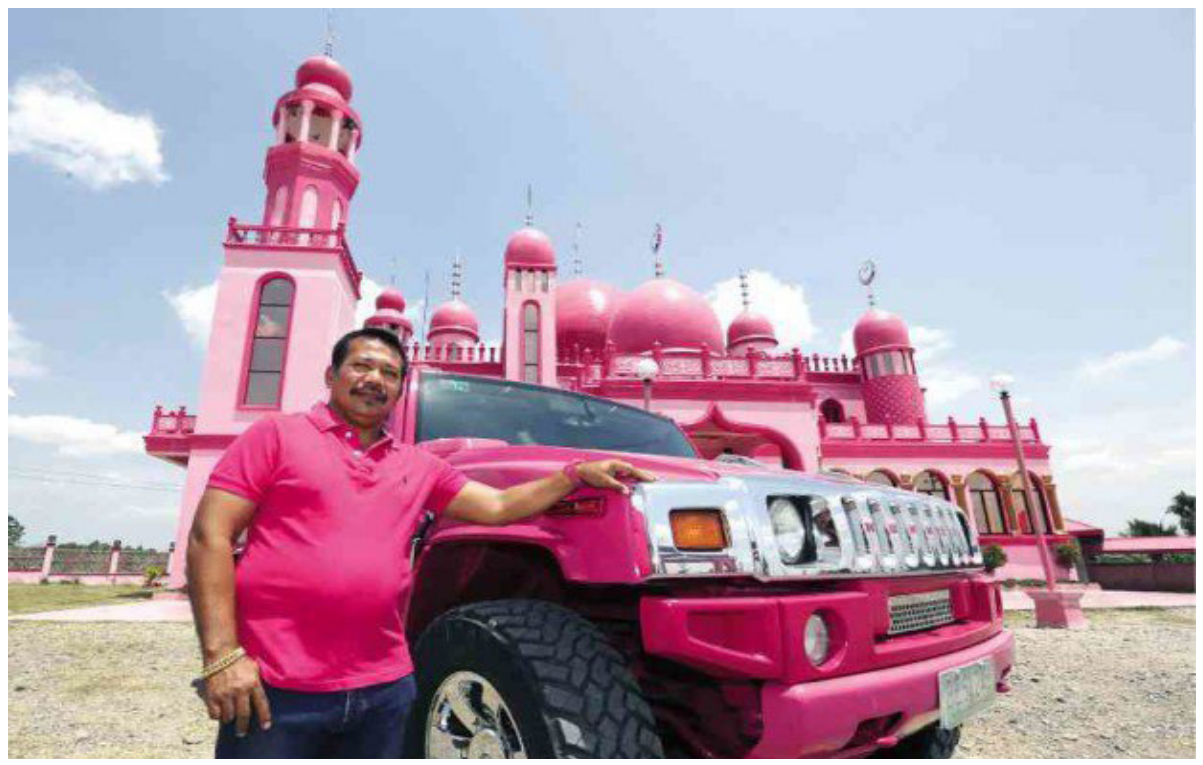

Figure 23. "Color of Love," Motioncars, Philippine Daily Inquirer, 03 November 2016. Retrieved from http://newsinfo.inquirer.net/835698/end-of-the-road-for-mayor-on-drug-list-9-others Copyright 2016 by Philippine Daily Inquirer. 


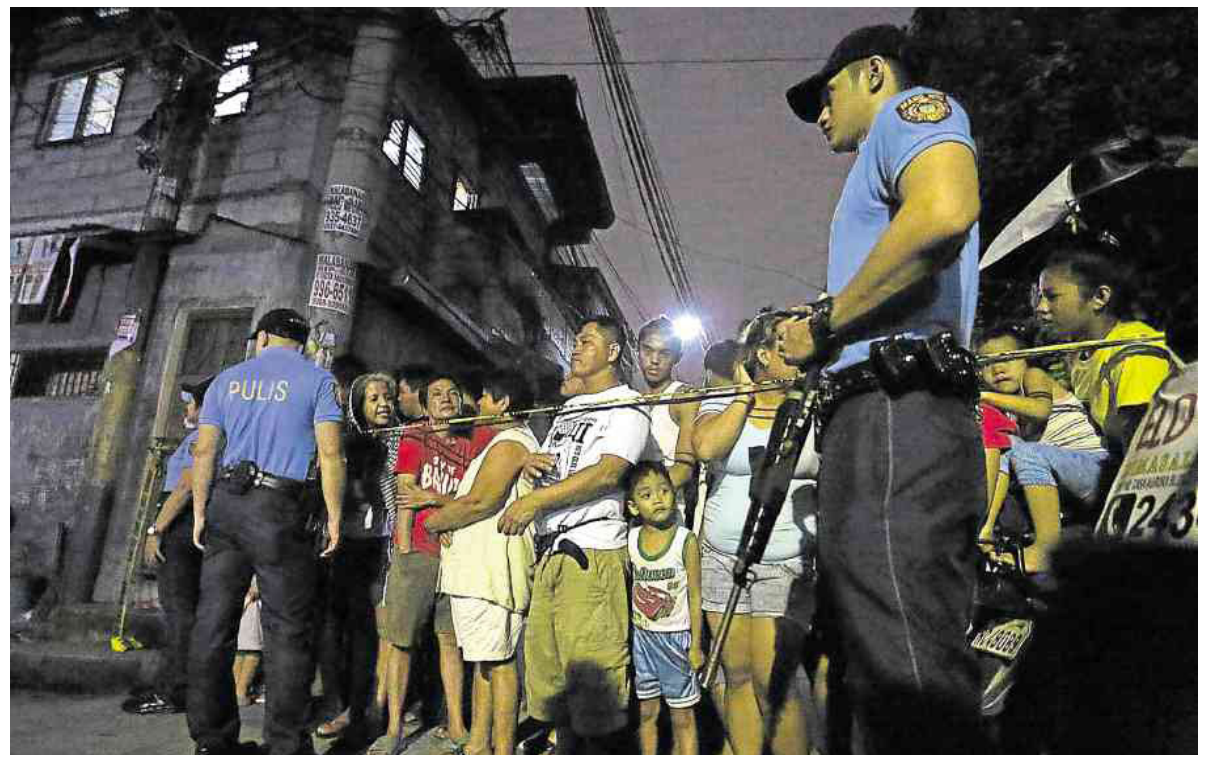

Figure 24. "Policemen Keep a Curious Crowd. . . from a Crime Scene," News Information/ Headlines, Philippine Daily Inquirer, 21 November 2016. Retrieved from http://newsinfo. inquirer.net/846158/drug-war-may-affect-kids-for-the-worse Copyright 2016 by Philippine Daily Inquirer.

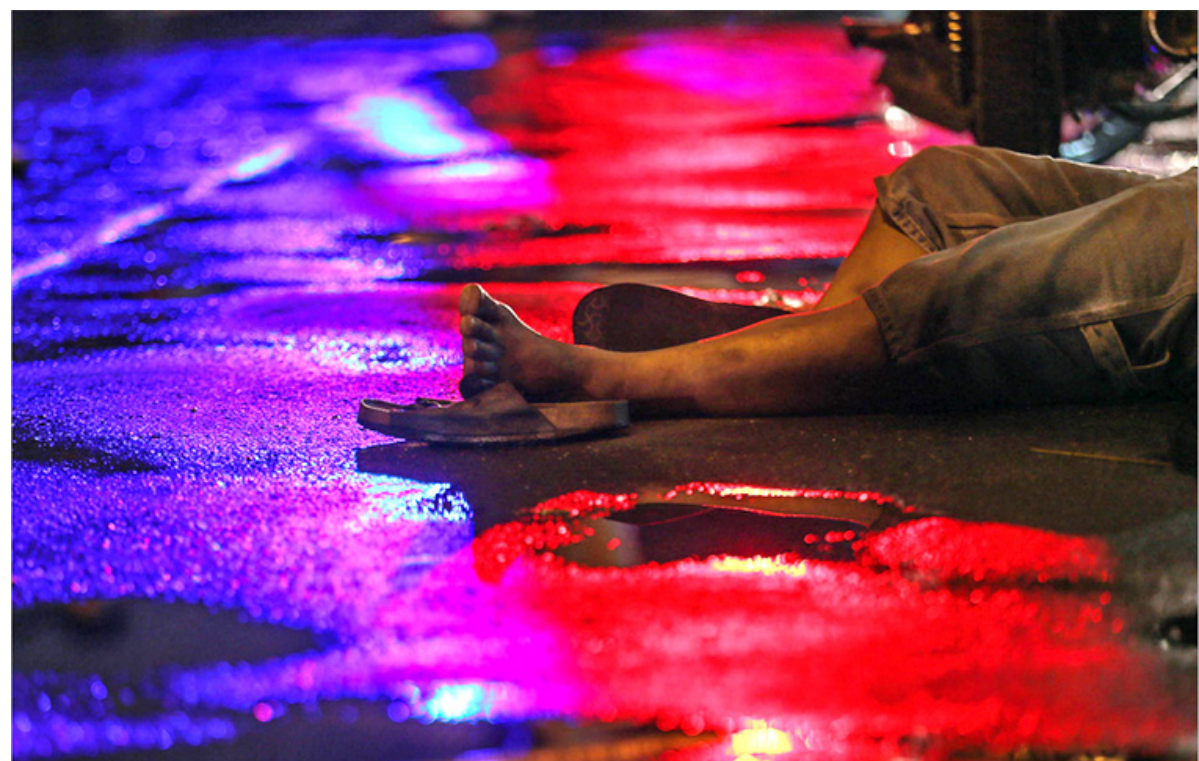

Figure 25. "Another Killed," Frame, Philippine Daily Inquirer, 22 November 2016. Retrieved from http://frame.inquirer.net/2960/another-killed-2/ Copyright 2016 by Philippine Daily Inquirer. 
Table 1 presents the images locations/classifications in the general layout of PDI to further emphasize their significance and circulation. It also shows that $40 \%$ of the selected photographs appear in the headlines; 20\% in Frame Magazine; 12\% in the special feature section; eight percent in the news information-Metro Manila section; another eight percent in the news information-regions section; and four percent each in the news information-featured gallery, news information-nation section, and Motioncars Magazine. Frame Magazine is a stand-alone photo-essay platform of PDI while Motioncars Maganizine is platform that is attached to the business section of PDI.

Table 1 shows as well that these images were published in between 06 July to 26 November 2016. A cursory investigation on the selected 25 photographs and their captions would reveal that 18 (72\%) were taken in Metro Manila; seven (28\%) outside Metro Manila, and one (4\%) outside of Luzon. This heavy concentration of images within Metro Manila is understandable since Lerma is based in this megacity. Of the 25 images, 11 (44\%) are related to police operations; ten (40\%) are related to the dreaded extrajudicial killings involving unknown assailants; one (4\%) is both related to police operations and extrajudicial killings; and three (12\%) are not related to either police operations or extrajudicial killings. Of the 25 images, $11(44 \%)$ directly portray a dead victim.

Table 1: Location/Classification of the Images within The Philippine Daily Inquirer

\begin{tabular}{|c|c|c|c|}
\hline $\begin{array}{l}\text { Location/ } \\
\text { Classification }\end{array}$ & Image and Title & Date Published & $\begin{array}{c}\text { Number of } \\
\text { Images } \\
\text { (Percentage) }\end{array}$ \\
\hline \multirow{8}{*}{ Headlines } & Figure 1. “Lamentation” & $04 \mathrm{Jul} 2016$ & \multirow{8}{*}{ (40\%) } \\
\hline & $\begin{array}{l}\text { Figure 3. "Confessed Users } \\
\text { Undergo a Drug Test in } \\
\text { Camp Karingal" }\end{array}$ & $07 \mathrm{Jul} 2016$ & \\
\hline & $\begin{array}{l}\text { Figure 6. "Pray You Don't See } \\
\text { this on Your Street" }\end{array}$ & $20 \mathrm{Jul} 2016$ & \\
\hline & Figure 8. "Salvage Victims" & $22 \mathrm{Jul} 2016$ & \\
\hline & $\begin{array}{l}\text { Figure 9. "Dark Side of Drug } \\
\text { War" }\end{array}$ & $30 \mathrm{Jul} 2016$ & \\
\hline & $\begin{array}{l}\text { Figure 15. "Latest Four to } \\
\text { Fall" }\end{array}$ & 10 Sep 2016 & \\
\hline & $\begin{array}{l}\text { Figure 16. "Drug Suspects } \\
\text { Arrested in Two Raids" }\end{array}$ & 18 Sep 2016 & \\
\hline & $\begin{array}{l}\text { Figure 17."Nunoy (Coloma) } \\
\text { was Gunned Down by Still } \\
\text { Unidentified Persons" }\end{array}$ & 26 Sep 2016 & \\
\hline
\end{tabular}




\begin{tabular}{|c|c|c|c|}
\hline & $\begin{array}{l}\text { Figure 17. "Ranilo Maydan, } \\
\text { Jr.'s Bullet-Riddled Body Lies } \\
\text { in Front of his House" }\end{array}$ & 24 Oct 2016 & \\
\hline & $\begin{array}{l}\text { Figure 24. "Policemen Keep } \\
\text { a Curious Crowd. .. from a } \\
\text { Crime Scene" }\end{array}$ & 21 Nov 2016 & \\
\hline \multirow{3}{*}{ Special Feature } & $\begin{array}{l}\text { Figure 18. "After a Small } \\
\text { Fight. . . these Men are Made } \\
\text { to Stick Together" }\end{array}$ & 08 Oct 2016 & \multirow{3}{*}{$\begin{array}{c}3 \\
(12 \%)\end{array}$} \\
\hline & $\begin{array}{l}\text { Figure 20. "At the Mess } \\
\text { Hall, an Altar with Religious } \\
\text { Figures Watch over Patients" }\end{array}$ & 08 Oct 2016 & \\
\hline & $\begin{array}{l}\text { Figure 20. "Seagulls in } \\
\text { Tagaytay City Caters mostly } \\
\text { to Patients who can Afford } \\
\text { to Pay" }\end{array}$ & 08 Oct 2016 & \\
\hline $\begin{array}{l}\text { News Information- } \\
\text { Featured Gallery }\end{array}$ & $\begin{array}{l}\text { Figure 10. "The Body of an } \\
\text { Alleged Drug Pusher and } \\
\text { Robber" }\end{array}$ & 06 Aug 2016 & $\begin{array}{c}1 \\
(4 \%) \\
\end{array}$ \\
\hline $\begin{array}{l}\text { News Information- } \\
\text { Nation }\end{array}$ & $\begin{array}{l}\text { Figure 4. "A Drug } \\
\text { Dependent's Mug Shot is } \\
\text { Taken" }\end{array}$ & 14 Jul 2016 & $\begin{array}{c}1 \\
(4 \%) \\
\end{array}$ \\
\hline \multirow{2}{*}{$\begin{array}{l}\text { News Information- } \\
\text { Metro Manila }\end{array}$} & $\begin{array}{l}\text { Figure 11. "Family in } \\
\text { Anguish" }\end{array}$ & 19 Aug 2016 & \multirow[b]{2}{*}{$(8 \%)$} \\
\hline & $\begin{array}{l}\text { Figure 21."Drug Den Raid in } \\
\text { Quezon City" }\end{array}$ & 24 Oct 2016 & \\
\hline \multirow[t]{2}{*}{$\begin{array}{l}\text { News Information- } \\
\text { Regions }\end{array}$} & $\begin{array}{l}\text { Figure } 2 . \text { “Drug Users in } \\
\text { Many Parts of the Country } \\
\text { Have Surrendered to } \\
\text { Rehabilitation" }\end{array}$ & 06 Jul 2016 & \multirow{2}{*}{$\begin{array}{c}2 \\
(8 \%)\end{array}$} \\
\hline & $\begin{array}{l}\text { Figure 14. "Arrested Drug } \\
\text { Suspects" }\end{array}$ & 06 Sep 2016 & \\
\hline \multirow{5}{*}{ Frame Magazine } & $\begin{array}{l}\text { Figure 4. "Bato Destroys } \\
\text { 'Bato"' }\end{array}$ & 14 Jul 2016 & \multirow{5}{*}{$(20 \%)$} \\
\hline & Figure 7. "Policeman Killed" & $21 \mathrm{Jul} 2016$ & \\
\hline & $\begin{array}{l}\text { Figure 12. “Cop Killed in Buy- } \\
\text { Bust Operation" }\end{array}$ & 20 Aug 2016 & \\
\hline & $\begin{array}{l}\text { Figure } 13 . \text { "Waiting to } \\
\text { Testify" }\end{array}$ & 23 Aug 2016 & \\
\hline & Figure 25. "Another Killed" & 22 Nov 2016 & \\
\hline $\begin{array}{l}\text { Motioncars } \\
\text { Magazine }\end{array}$ & Figure 23. "Color of Love" & 03 Nov 2016 & $\begin{array}{c}1 \\
(4 \%)\end{array}$ \\
\hline
\end{tabular}




\section{A Counter-Semiology Based on the Early Barthes}

As already mentioned, the hermeneutic lens that was used in the analysis of Lermás selected 25 images is the semiology of the early Barthes. The choice of this hermeneutic framework was based on three things. First, the thrust of the semiology of the early Barthes on political and ideological readings dovetailed well with the kind of political and ideological-or more precisely counter-political and counter-ideological-analyses intended in this paper. Second, the semiology of the early Barthes' actual engagements with the study of photojournalistic images also dovetailed well with the nature of this paper, which also studies particular photojournalistic images. Third, which is the most circumstantial among the three reasons, the author of this paper has already used the semiology of the early Barthes in two published papers and has already supervised two dissertations based on the same hermeneutic framework. The said author, therefore, has the confidence not only to use again the semiology of the early Barthes but more so to experiment on inverting it to serve the specific nature of this paper of understanding counter-political and counterideological discourses launched by a less privileged sector of Philippine society.

The main sources of this paper's appropriation of the semiology of the early Barthes are his essays "Myth Today" (1972a); "Photography and Electoral Appeal” (1972b); “The Great Family of Man” (1972c); "Shock Photos” (1988); "The Photographic Message" (1977a); and "Rhetoric of the Image" (1977b). Among these six essays, "Myth Today" is the most articulated theoretical and methodological work, followed by "The Photographic Message" and "Rhetoric of the Image." The essays "Photography and Electoral Appeal," "The Great Family Man" and "Shock Photos" are applied works that deal with specific photographs or clusters of photographs. The laying down of the semiology of the early Barthes in this essay, therefore, centers on the essay "Myth Today," and the other two theoretical and methodological essays are used as auxiliary sources. The three applied essays are used in the succeeding section as templates on how to operationalize the semiology of the early Barthes.

Barthes' project of probing into the hidden discourses behind cultural icons, images, and photographs was founded on the thoughts of three great figures of modern western philosophy: Karl Marx (1818-1883), Ferdinand de Saussure (1857-1913), and Sigmund Freud (1856-1939) (Barthes, 1972a). The German philosopher Marx believed that the elements of culture, especially those that mesmerize and tame the masses such as art, literature, and religion, are there in order to conceal the deep-seated contradictions created by the then-emerging capitalist system (Wolff, 2015). This Marxist insight inspired Barthes to unearth the hidden discourses behind some icons of popular culture. Meanwhile, the Swiss linguist Saussure was convinced about the necessity of establishing a science that would deal with the sign, which he named "semiology" (Barthes, 
1972a). Saussure, furthermore, was the one who conceptualized the structure of the sign as constituted by the "signifier" or the visual or acoustic image, and the "signified" or concept or mental image (Barthes, 1972a). "Myth Today" and its preceding essays in the collection Mythologies were Barthes' attempt to construct his own semiology based on the Saussurian conception of the sign. The Austrian physician, neurologist, and founder of psychoanalysis Freud, on the other hand, thought that some distinctive dreams are in effect signs of mental elements that are based on a given individual's experiences and desires (Barthes, 1972a). He endowed what formerly was merely an occult practice of interpretation of dreams with a scientific and rational form. He used his own version of interpretation of dreams as one method for his bigger project of psychoanalysis that was geared towards the organization and narrativization of some of the conscious and unconscious experiences and desires of individuals (Barthes, 1972a). From Freud, Barthes gleaned the insight that semiology is not different from the interpretation of dreams in the sense that semiology is also the process of narrativizing the unconscious discourses that are concealed beneath some icons of popular culture.

As already mentioned, Barthes (1972a) appropriated the construct of the sign, as constituted by the signifier and the signified, that was created by Saussure:

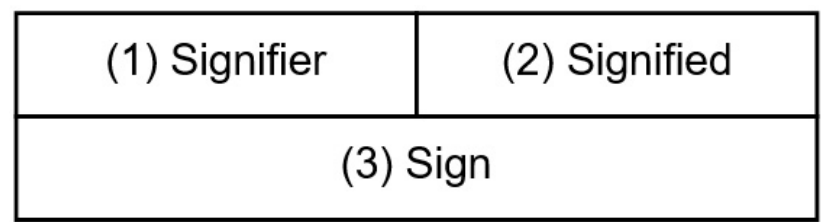

Figure 26: The Sign according to Saussure (2016).

This Saussurian construct was specifically used by Barthes to build his first level of conceptualization, which he referred to as the level of language. In his essay "The Photographic Message," Barthes (Barthes, 1977a) called the meaning produced by a photographic image in this level "denotation" (p. 17). Because Barthes' semiology is supposed to go deeper than what Saussure had started, this Saussurian construct only served as stepping stone for his conceptualization of the myth (Barthes, 1972a, p. 113). Myth, for Barthes, has nothing to do with ancient legends or folklores. Rather, his usage of the word is closer to "contemporary beliefs" or "knowledges that are devoid of solid bases or foundations" (1972a, p. 107). In addition, myths are discourses that are both visible and hidden beneath some icons of a given society, especially icons of popular culture.

Figure 27 shows how Barthes built another construct on Saussure's construct in order to conceptualize the Barthesian myth. The Saussurian 


\begin{tabular}{|c|c|c|}
\hline (1) Signifier & (2) Signified & \\
\hline (4) & IER & (5) SIGNIFIED \\
\hline \multicolumn{3}{|c|}{ (6) SIGN } \\
\hline
\end{tabular}

Figure 27: The Myth as a Deeper Sign according to Barthes (1972a)

sign (3) at the level of language stands as the Barthesian signifier (4) at the level of the Barthesian myth or at the level of signification. Mythology, therefore, pertains to Barthes' proposed system on how to deal with these contemporary myths. In the essay "The Photographic Message," Barthes (Barthes, 1977a) called the meaning produced by a photographic image in this level "connotation" (p. 19).

Because the terms "signifier," "signified," and "sign" were used twice in his construct of the myth, Barthes decided to replace some of them with more technical terms. Hence, the signified (2 and 5) was renamed "concept"; the signifier in the second level (4) was renamed "meaning," as it is the end element of the Saussurian construct, and at the same time "form," as it is the starting element of the deeper construct of the myth; and the sign in the first level (6) was renamed "signification" (cf. Barthes, 1972a). Figure 3 shows the more articulated Barthesian construct of the myth:

\begin{tabular}{|c|c|c|}
\hline (1) Signifier & $\begin{array}{c}\text { (2) Signified } \\
\text { (Concept) }\end{array}$ & \\
\hline \multicolumn{2}{|c|}{ (3) Sign } \\
(4) SIGNIFIER (Meaning/Form) & (5) SIGNIFIED (Concept) \\
\hline \multicolumn{2}{|c|}{ (6) SIGN (Signification) } \\
\hline
\end{tabular}

Figure 28: The More Articulated Construct of the Myth According to Barthes (1972a).

Through this more articulated construct of the myth, Barthes (1977a) was able to show clearly the complex characteristics of the signifier (4 in Figures 27 and 28) that behave as meaning in as far as the Saussurian construct of the sign is concerned, and as form in as far as the Barthesian construct of the myth is concerned. According to Barthes, the oscillation of the signifier ( 4 in Figures 27 and 28) between meaning and form or between being filled and empty is what opens the possibility for it to be filled with a deeper signified (5 in Figures 27 and 28) so as to create in the process a new sign (6 in Figures 27 and 28) or signification or myth. Connotation and myth are therefore not exactly the same. Connotation in a photographic 
image can be there without the intention of the photographer, whereas myth is something that is intentionally tucked by an agent or group of agents beneath a cultural icon. Myth, therefore, is a special kind of connotation that is marshalled to serve the interests of a given agent or group of agents. In photographic images, the marshalling of connotations is possible because photographs are objects that have "been worked on, chosen, composed, constructed" (p. 19) framed, reduced, flattened and "treated according to professional, aesthetic or ideological norms" (1977b, p. 36).

As Barthes (1972a) studied the myths nestled in some icons of popular culture, he was able to catalogue at least seven rhetorical strategies used by the dominant social groups in propagating such myths. First among these is the process of inoculation or vaccination, which for him is about the discussion or admission of some small evils so as to distract the attention of the people from the bigger and more ingrained evils. Second is the erasure of history which is intended to turn the people's attention on the present and prevent them from taking a deeper and wider historical look at a given issue. A critical retrospect would usually reveal suspicious details. Third among these rhetorical strategies is the process of identification, and this has something to do with the manipulation of the representation of the nonelite and non-elitist practices and ways of life in accordance with the image and terminologies of the elite. In the strategy of identification, individuals, practices, and ways of life that cannot actually be represented as elite are simply packaged as exotic spectacles or things that may be different but are actually devoid of significance in the world of the elite. The fourth strategy is the use of tautology or the way of reasoning and explaining that states the very same thing that needs to be justified or explained in the first place. Thus, in traditional logic, tautology is also called "circular reasoning." The fifth strategy is known as "neither-norism" or the reduction of a situation as merely consisting of two alternatives, which is followed by insinuations that neither of the two alternatives is a good option. Sixth among these rhetorical strategies is the quantification of quality, and this has something to do with the modern-day bias of measuring all things in terms of money and numbers. The seventh strategy is the statement of the fact, similar to tautology but made more elegant through the use of traditional sayings. Barthes did not close the possibility of the existence of other rhetorical strategies that he may have failed to catalogue.

It must be noted, however, that the seven rhetorical strategies mentioned by Barthes (1972a) pertain to the strategies mobilized by the dominant social groups. Since Lerma is actually grappling with the more powerful Duterte administration, this paper assumes that the photojournalist's putative rhetorical strategies are actually counter-strategies to the ones 
mentioned by Barthes. Hence, instead of inoculation, Lerma would be pursuing counter-inoculation that would make his viewers/audience aware of the graver evils hidden behind the smaller evils; instead of erasure of history, historization and re-contextualization that would provide his viewers/audience some critical circumspection and retrospection on an issue at hand; instead of identification and exotization, dis-identification and normalization that would respectively safeguard the difference of the lower social classes and connect their relevance to the other social classes; instead of tautology, counter-tautology that would break the circular reasoning of whosoever is propagating a given myth; instead of neithernorism, counter-neither-norism that would proffer to his viewers/audience some other viable alternatives; instead of quantification of quality, the insistence on the significance of quality; and instead of statement of fact, counter-statement to the fact that would also elegantly break any elegantly propagated tautology.

By sticking with the reverse processes of the Barthesian rhetorical strategies, this paper theoretically tests the capacity of Barthes' semiology to tackle not only ideological discourses that are tucked beneath some sociocultural icons but more so counter-ideological discourses that are launched by the less privileged sectors of a given society. In this counterBarthesian semiology, the myth or the ideological discourse becomes Lerma's counter-discourse against the drug war of the Duterte administration.

\section{Counter-Semiological Analyses}

A careful examination of each of the 25 selected photographs of Lerma yielded five recurrent sociocultural icons: 1 ) poverty; 2 ) the dehumanization/ demonization of the casualties; 3 ) religion; 4) the weakness of governance in the Philippines; 5) Operation Plan Tokhang conducted by the Philippine National Police (PNP); and 6) the state and the nation. Table 2 presents the frequency of occurrence or recurrence of each icon and the images in which each icon is reflected.

Table 2: Socio-Cultural Icons from Specific Images and the Frequency of their Occurrences

\begin{tabular}{|l|c|l|}
\hline \multicolumn{1}{|c|}{ Sociocultural Icons } & Frequency & \multicolumn{1}{c|}{ Specific Figures } \\
\hline Poverty & 12 & $\begin{array}{l}1,6,7,9,11,14,16,17,21, \\
22,24, \& 25\end{array}$ \\
\hline $\begin{array}{l}\text { Dehumanization/Demonization of the } \\
\text { Casualties }\end{array}$ & 7 & $1,6,8,10,15,16, \& 22$ \\
\hline Religion & 6 & $1,7,12,17,19, \& 23$ \\
\hline $\begin{array}{l}\text { Weakness of Governance in the } \\
\text { Philippines }\end{array}$ & 6 & $1,9,21,22,23, \& 25$ \\
\hline
\end{tabular}




\begin{tabular}{|l|l|l|}
\hline PNP's Operation Plan Tokhang & 5 & $2,3,4,14, \& 16$ \\
\hline The State and the Nation & 3 & $3,17, \& 25$ \\
\hline
\end{tabular}

The visual significations of these six sociocultural icons and the way Lerma represented them are thoroughly and textually analyzed in the succeeding subsections. It must be noted that in a Barthesian semiological analysis, the individual propagator of a given signification may or may not be totally conscious of the full dimension of his or her signification or even of the act itself of propagating such signification, just as the photographers or producers of the various cultural icons examined in Mythologies were not even individually identified by Barthes nor attributed agencies of the significations that he culled ex post facto from the said cultural icons.

\section{Poverty}

Table 2 shows that among the six sociocultural icons identified by this paper, poverty is the most recurrent, as it appears in figures $1,6,7,9,11$, $14,16,17,21,22,24$, and 25. In figure 1 ("Lamentation") (Lema 2016a), the most iconic image that Lerma had been able to take from the raging drug war, poverty is personified in the lifeless body of the pedicab driver, as well as in his grieving live-in partner. The rear part of the pedicab is visible in the upper left corner of the image. In Metro Manila and in many places in the country, pedicab drivers live well below the poverty line (Gozun \& Guillen 2008). In figure 6 ("Pray You Don't See this") (Lerma, 2016b) poverty is expressed in the short pants and calloused feet of the dead victim. The short pants and calloused feet are signs that the casualty did not have a regular job and was so poor that he could not buy himself a pair of shoes. In figure 7 ("Policeman Killed") (Lerma, 2016k), poverty is articulated by the slippers, short pants, and sleeveless undershirt of the slain suspect, as well as by the untidy foreground of a sari-sari store (Filipino convenience store). In figure 9 ("Dark Side of Drug War") (Lerma, 2016m), it is made concrete by the makeshift shack that was informally built directly above an open sewer that is choking with garbage. The owner of the shack is the same pedicab driver in figure 1 ("Lamentation") (Lerma, 2016a).

In figure 11 ("Family in Anguish"), (Lerma, 2016d) poverty is conveyed by the untidy neighborhood and cheap and threadbare outfits of the mourning relatives and friends. In figure 14 ("Arrested Drug Suspects") (Lerma, 2016w), it is seen through the slippers and short pants of the arrested suspects. In figure 16 ("Drug Suspects Arrested in Two Raids") (Lerma, 2016y), it is expressed by the slippers, calloused feet, short pants, and cheap and threadbare garments of the arrested suspects. The suspects' capacity to easily sleep on the bare concrete basketball court hints of their 
being used to sleeping on mattress-less beds or floors. In figure 17 ("Nunoy was Gunned Down") (Lerma, 2016z), poverty is suggested by the slippers and face towel of the casualty. Face towels are a common accessory among Filipino low-income drivers and manual laborers, used every now and then to wipe dry their sweaty faces and bodies. In figure 21 ("Drug Den Raid") (Lerma, 2016u), poverty is indicated by the slippers and cheap and threadbare clothes of the arrested suspects as well as by another pedicab. In figure 22 ("Ranilo Maydan, Jr.s Bullet-Riddled Body") (Lerma, 2016v), poverty is implied by the untidy surroundings as well as by a parked tricycle, which, in the Philippines, is just a notch higher than the pedicab. In figure 24 ("Policemen Keep a Curious Crowd") (Lerma, 2016p), it is suggested by the rather depressed surroundings, more particularly by the unplastered and unpainted two-story house to the left of the background. In figure 25 ("Another Killed") (Lerma, 2016q), it is deemed from the slippers and short pants of the slain suspect, as well as from the lower rear portion of a tricycle.

After analyzing Lerma's 25 photographs using Barthes, it is clear that under the counterstrategies of historization and re-contextualization, as well as normalization, the multiple and diverse references to poverty have been putatively mobilized to show that if the majority of the victims and suspects of the raging drug war are impoverished Filipinos, then there must be something unjust about the whole drug war. The counterstrategy of historization and re-contextualization, as the reverse of the Barthesian strategy of erasure of history, specifically brings into the consciousness the situation on the ground, where the poor casualties of the drug war far outnumber the casualties from other socioeconomic classes. This counterstrategy of historization and recontextualization makes Lerma's audience realize that the drug war is trampling on a vulnerable sector of the Philippine society. The counterstrategy of normalization, as the reverse of the Barthesian strategy of exotization, goads Lerma's audience to realize that these impoverished casualties are not subhuman and are therefore deserving of the kind of treatment accorded to the suspects from the other socioeconomic classes. The counterstrategy of normalization reconnects the casualties to the audience of the pertinent photographs, not necessarily on the basis of a shared social class but on the basis of a shared humanity.

Lerma's signification of poverty becomes clearer if contrasted with figures 5, 12, 18, 19, 20, and 23. Figure 5 ("Bato Destroys 'Bato") (Lerma, $2016 \mathrm{j}$ ) shows the PNP Chief destroying bags of shabu (methamphetamine) that were most probably seized from raids on big laboratories and safe houses that seldom involve actual arrests or killings. Figure 12 ("Cop Killed in Buy-Bust Operation") (Lerma, 2016e) presents a picture of a fallen police officer, but noticeably, he is in a neat, sanitized, and respectable location 
of a hospital room. Figures 18 ("After a Small Fight") (Lerma, 2016r) and 19 ("At the Mess Hall") (Lerma, 2016s) display the luckier inmates who are in an upscale private rehabilitation center. The resort-like exterior of such center is indicated in figure 20 ("Seagulls in Tagaytay City") (Lerma, 2016t). The name "Seagulls" could allude to the easily available option of just flying away from the terrors of the raging drug war for those who can afford to be in such kind of rehabilitation centers. Lastly, figure 23 ("Color of Love") (Lerma, 2016n) shows a wealthy mayor able to finance his pink obsession. But this is a rare image in the drug war, for it is just one of the very few showing a casualty from the upper class.

\section{The Dehumanization/Demonization of the Casualties}

Table 2 shows the dehumanization/demonization of the casualties as the second most recurrent sociocultural icon, as it appears in figures 1, 6, 8, 10, 15,16 , and 22. Dehumanization is the act of symbolically stripping away the humanity of an individual such that the sympathy that other human beings usually accord to fellow human beings is lost. Demonization is also a symbolic act, though this time the individual is portrayed as an evil monster and deemed deserving of whatever misfortune that befalls him or her.

The dehumanization/demonization of the casualty is expressed in figure 1 ("Lamentation") (Lerma, 2016a) through the cardboard sign accusing him of being a drug pusher. This is also articulated in a similar cardboard sign in figure 6 ("Pray You Don't See this") (Lerma, 2016b), as well as by the casualty being hogtied and placed inside a sack, just like how smaller farm animals are often transported in the rural areas of the country. In figure 8 ("Salvage Victims") (Lerma, 20161), the dehumanization/demonization of the casualties is conveyed by the women being hogtied, as well as by the tell-tale packaging tape wrapped around their heads, intended it seems to physically obliterate their identities and humanity. Killings like these are usually done in one place before the bodies are dumped somewhere elsesome dark and less frequented part of the metropolis.

The dehumanization/demonization is conveyed in figure 10 ("The Body of an Alleged Drug Pusher") (Lerma, 2016c) still by another cardboard sign accusing the casualty of being a drug pusher and a robber, by the way his hands are tied, and by the packaging tape around his head; in figure 15 ("Latest Four to Fall") (Lerma, 2016x), by the unceremonious dumping of some four cadaver bags on what looks like a backyard; in figure 16 ("Drug Suspects Arrested in Two Raids") (Lerma, 2016y), by the manner the suspects are sleeping on the bare concrete floor, which resembles the typical condition in which the drug war casualties are found; and in figure 22 ("Ranilo Maydan, Jr.s Bullet-Riddled Body") (Lerma, 2016v), by the way 
the casualty is sprawled on a filthy corner just beside a sack of garbage and the graffiti "Bawal Umihi" (Do Not Urinate) that could evokes the stench of urine that Filipinos know too well to suffuse the nooks and crannies of their cities.

Under the counterstrategies of counter-inoculation, normalization, and historization and re-contextualization, the various references to the dehumanization/demonization of the casualties are putatively mobilized to contest the extrajudicial killings that simultaneously accuse and execute the suspects without the benefit of a fair trial and sentence/acquittal. Counter-inoculation, the reverse of the Barthesian strategy of inoculation, specifically dissipates the spreading public opinion that killing suspects is a lesser evil compared to the havoc that it has spawned on Philippine society. Counter-inoculation does not actually condone drug trafficking in the pertinent photographs but argues that killing suspected drug traffickers there and then could even be a bigger social evil. Normalization, the reverse of the Barthesian strategy of exotization, specifically drives home the point that the casualties that have been dehumanized and demonized by the drug war are in fact human beings who may not even be guilty of the crime they had been summarily accused of.

The counterstrategy of historization and re-contextualization, as the reverse of the Barthesian strategy of erasure of history, becomes clearer using figures $1,9,11$, and 13. Although dehumanization/demonization had already been noted in figure 1 ("Lamentation") (Lerma, 2016a), the presence of the grieving live-in partner of the slain pedicab driver re-contextualizes the humanity and presumptive innocence of the casualty. In figure 9 ("Dark Side of Drug War") (Lerma, 2016m), the makeshift shanty of the pedicab driver challenges the cardboard accusation that he was a drug pusher, for it begs the question, "If he were indeed a drug pusher, how come he was still living over this garbage-clogged sewer?" In figure 11 ("Family in Anguish") (Lerma, 2016d), the grieving relatives and friends restore the humanity of the casualty, for if they can cry and mourn for him, there must have been enough goodness in him to challenge his demonization. Lastly, in figure 13 ("Waiting to Testify") (Lerma, 2016f), the relatives of some casualties are preparing to tell their grievances to the Philippine Senate.

There are two interesting images of Lerma that had not been captured by the selection process for this paper for the reason that they were not published in PDI. But their vividness serves as counterstrategies for redeeming the humanity of the casualties as well as dissipating their demonization and compels the researcher to mention them as supplementary materials.

In figure 29 ("A Coroner cuts through the Packaging Tape") (Lerma, 2016o), the coroner is removing the packaging tape that wraps the casualty's 


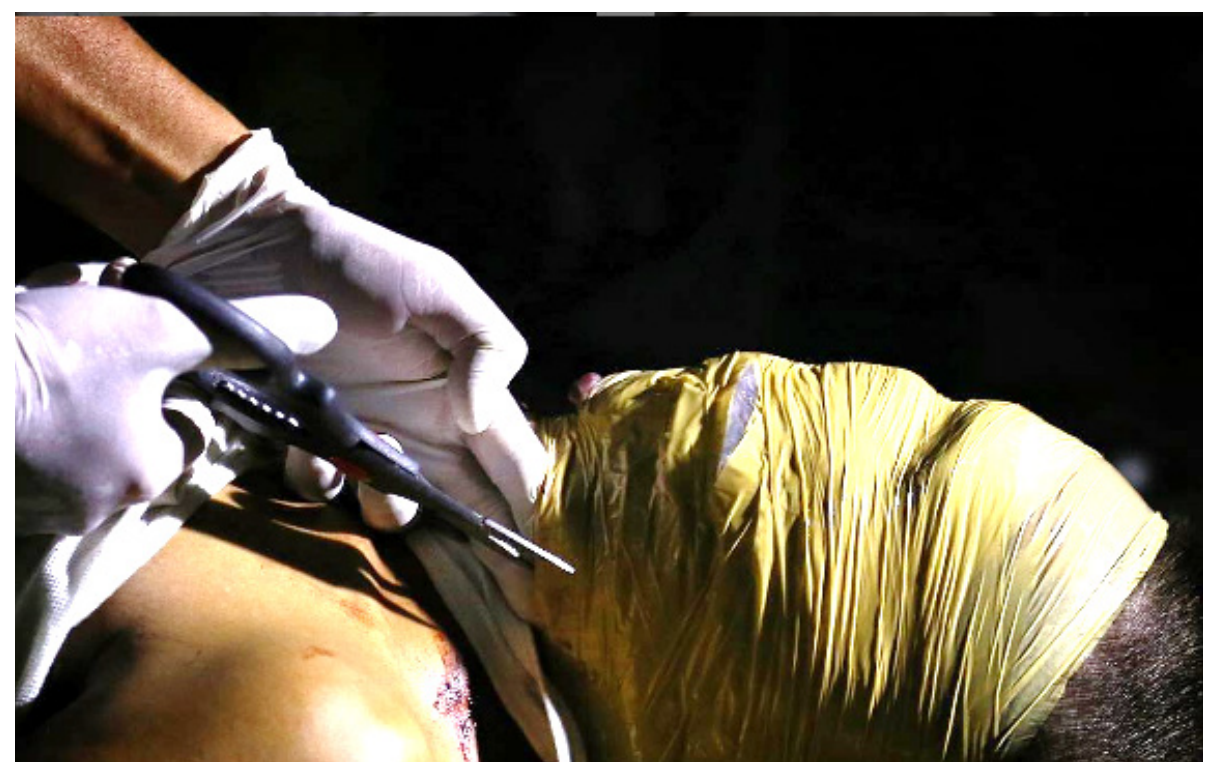

Image 29. "A Coroner Cuts through the Packaging Tape that Concealed the Face of a Victim of Summary Execution." Reprinted from Raffy Lerma's Instagram Account, 16 Nov 2016, retrieved from https://www.raffylerma.com/nightshift Copyright 2016 by Rafael Lerma. Reprinted with permission.

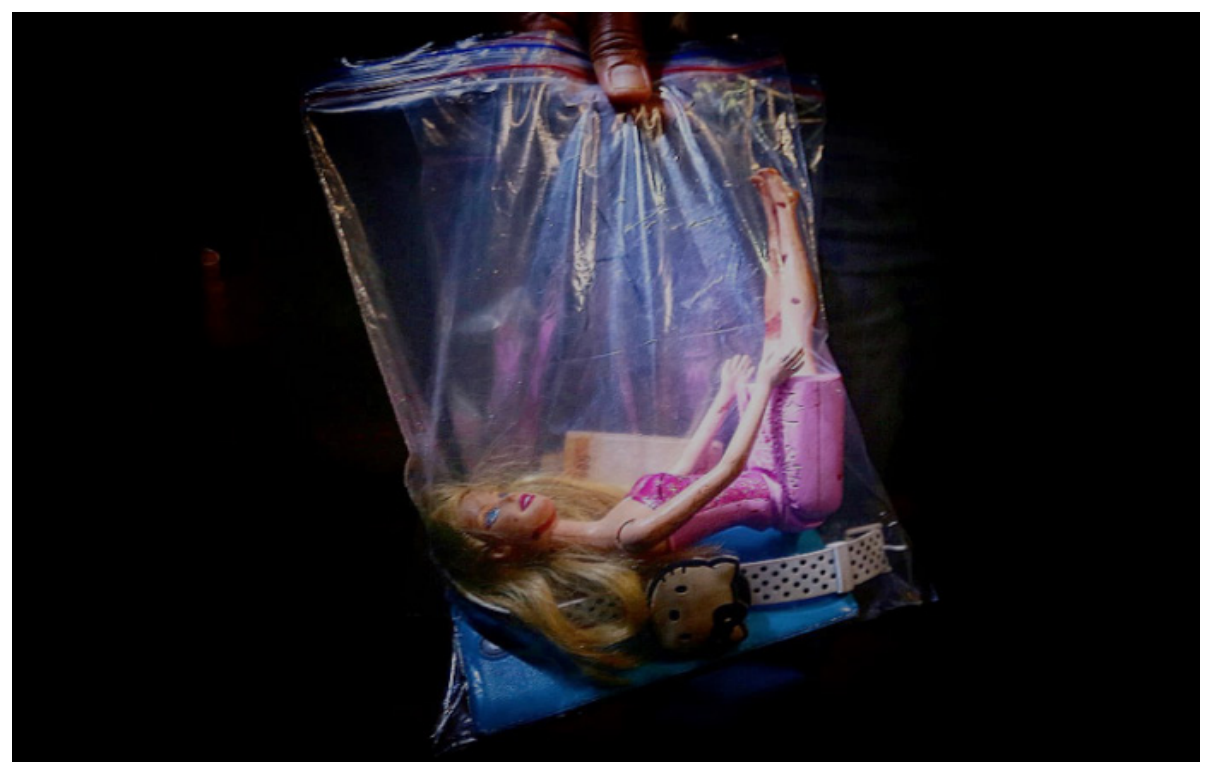

Figure 30. Plastic Doll Stained with Blood, a Wristwatch and a Wallet that Belonged to a Slain 17 Year Old Girl. Reprinted from Raffy Lerma's Instagram Account, Undated, retrieved from https://www.raffylerma.com/nightshift Copyright 2016 by Rafael Lerma. Reprinted with permission. 
head, as if to symbolically restore his humanity. In figure 30 ("Plastic Doll Stained with Blood") (Lerma, n.d.), the items recovered from a slain girl signify her childhood innocence that could contest the cardboard accusation, “Tulak Ka, Hayop Ka," (You are a Pusher, You are a Beast) that she and her slain boyfriend were left with. In these poetic images, the counterstrategy of counter-statement to the fact, the reverse of the Barthesian strategy of statement of fact, is also used to achieve signification.

\section{Religion}

Table 2 shows that religion and weakness of governance in the Philippines are tied for third place in terms of frequency among the six sociocultural icons identified in this paper. Religion is alluded to in figures $1,7,12,17,19$, and 23. Figure 1 ("Lamentation") (Lerma, 2016a) has an eerie resemblance to La Pietà by the Italian artist Michelangelo Buonarroti (1475-1564). In that magical instant documented by Lerma, the widowed live-in partner became the Virgin Mary, while the pedicab driver became Jesus Christ. Even President Duterte himself, in his 26 July 2016 State of the Nation Address, revealed that he recognized the dramatic resemblance (Esmaquel, 2016). In figure 7 ("Policeman Killed") (Lerma, 2016k), a poster of the crowned Jesus Christ showing his sacred heart, which is supposed to be the fountain of love and mercy for humanity, hovers above the casualty. Figure 12 ("Cop Killed in Buy-Bust Operation") (Lerma, 2016e) shows the slain policeman's widow, who appears to be silently praying. In figure 17 ("Nunoy was Gunned Down") (Lerma, 2016z), the posture of the fallen victim resembles the inverted figure of the crucified Jesus Christ. In figure 19 ("At the Mess Hall") (Lerma, 2016s), there is an altar that displays the almost life-size statues of the Jesus Christ with again his sacred heart, and of the Lady of Lourdes. In figure 23 ("Color of Love") (Lerma, 2016n), the pink mosque built by the extremely rich mayor cannot be ignored.

Under the counterstrategies of counter-statement to the fact and dis-identification, allusions to religion have been putatively mobilized to question the religiosity of the Filipinos. Counter-statement to the fact, the reverse of the Barthesian strategy of statement of fact, specifically critiques how Filipinos ordinarily think of themselves as religious people yet at the same time fail to exhibit a moral outcry in the face of the rising number of summary executions that are related to the raging drug war. Figures 1 ("Lamentation") (Lerma, 2016a) and 7 ("Policeman Killed") (Lerma, 2016k) are poetic in delivering such signification. These allusions to religion may not be raising the metaphysical question "Where is God when his beloved people were decimated by unknown assailants?" but are raising the social and political question "Where are the God-fearing and God-loving 
Filipinos when so much killing is happening in their land?" During the data gathering stage for this paper, the Philippine Roman Catholic hierarchy had no sustained and systematic plans against the drug war of the Duterte administration. To date, its reaction is still not sustained and systematic enough to pressure the said administration to rethink such war.

On the other hand, the counterstrategy of dis-identification, the reverse of the Barthesian strategy of identification, specifically proffers the case that religion in the Philippines favors the upper social classes. Whereas religion seems deaf to the plight of the lower class as seen for example in figures 1 ("Lamentation") (Lerma, 2016a), 7 ("Policeman Killed") (Lerma, 2016k), and 17 ("Nunoy was Gunned Down") (Lerma, 2016z), it seems to bring comfort and efficacy to those from the upper social classes, as seen in such figures as 12 ("Cop Killed in Buy-Bust Operation") (Lerma, 2016e) and 19 ("At the Mess Hall”) (Lerma, 2016s).

\section{Weakness of Governance in the Philippines}

As already mentioned, weakness of governance in the Philippines tied with religion as third most recurrent icons in this paper. In figure 1 ("Lamentation") (Lerma, 2016a), the weakness of governance is suggested by two visual cues: the signboard at the central background that says "Bawal Magsakay at Magbaba ng Pasahero Dito" (No Loading and Unloading of Passengers Here) and the pedicab at the upper left corner. The photograph was taken just below a metro rail line and beside another metro rail line, and the two visual cues say a lot about the chaotic state of the megacity's public transportation. The signboard is intended for unruly drivers of jeeps and buses that serve to meet a huge portion of Metro Manila's public transportation needs. Because of their need to earn more income or reach their daily quota, these drivers allow passengers to board and alight from their vehicles almost anywhere along their routes. Meanwhile, the pedicab, unless it is intended to be a tourist attraction like the horse-drawn carriage in Manila's old walled city or Bangkok's tuktuk, is simply out of place in a megacity with more than ten million inhabitants.

Weakness of governance in the Philippines is also conveyed in figure 9 ("Dark Side of Drug War") (Lerma, 2016m), which shows an open sewer, the deluge of garbage, and a shack that seem to float above them. The image was not taken from a dumpsite or from some neglected fringes of the megacity but somewhere near its center. Figure 21 ("Drug Den Raid") (Lerma, 2016u) shows a pedicab on a side street and what looks like a gambling table that services a neighborhood even in the broad daylight. In figure 22 ("Ranilo Maydan, Jr.s Bullet-Riddled Body") (Lerma, 2016v), there are two visual cues: a tricycle, which as mentioned is just a notch higher than a pedicab, 
and the graffiti "Bawal Umihi. Putol Titi" (Do Not Urinate. Your Sex Organ will be Cut) with a pair of scissors in between the two phrases. The graffiti, written half-seriously and half-jokingly, betrays the Filipinos' high tolerance for unhygienic surroundings and the government's failure to enforce sanitary practices and provide public toilets. In figure 23 ("Color of Love") (Lerma, 2016n), weakness of governance is implicit in the figure of an alleged drug lord mayor, who embodies the shortcoming of the country's political system in filtering out leaders who are deficient in personal integrity. In figure 25 ("Another Killed") (Lerma, 2016q), it is implied again by another tricycle.

Under the counterstrategy of historization and re-contextualization, and counter-tautology, allusions to the weakness of governance in the Philippines have been putatively mobilized to raise doubts on the idea propagated by the Duterte administration that the drug menace is the greatest evil in Philippine society. These allusions could signify the need for a stronger and more rational governance, especially in Metro Manila where ten percent of its population resides. The problem of drugs could just be part of this general deficiency in governance. It is therefore unwise for the administration to spend much of its financial, political, and organizational capital on the drug war, at the expense of attending to the much needed rationalization and strengthening of Philippine governance.

\section{The Operation Plan Tokhang}

As Table 2 shows, Operation Plan Tokhang conducted by the PNP is the second least recurrent among the sociocultural icons as it appears only in figures 2, 3, and 4, although with interconnections with figures 14 and 16. Tokhang is a newly coined word as far as the Tagalog-speaking areas of Metro Manila are concerned. It is a portmanteau of the Cebuano terms toktok (knock) and hangyo (request), and the tokhang strategy consists of knocking at the doors of suspected drug pushers and users, and requesting them to surrender so that they can be monitored and eventually rehabilitated (Gregorio, 2018). Tokhang's Tagalog equivalent, kapak (from katok or knock, and pakiusap or request) was initially introduced in Metro Manila, but it did not gain popularity (Popioco, 2016).

In figure 2 ("Drug Users in Many Parts of the Country") (Lerma, 2016g), six individuals who surrendered due to said operation plan are shown lining up for an obligatory drug test, while the rest of their cohorts listen to some briefing, filling up a huge section of a basketball court. In figure 3 ("Confessed Users Undergo a Drug Test”) (Lerma, 2016h), three more individuals are shown lining up also for a drug testing. Figure 4 ("A Drug Dependent's Mug Shot") (Lerma, 2016i) shows the mugshot of a drug dependent who also surrendered because of Operation Tokhang. The huge number of those who 
surrendered and the lack of sophisticated information system, as well as strict protocols in processing such surrenders, expose the unpreparedness of the PNP in undertaking such an operation. Figures 14 ("Arrested Drug Suspects") (Lerma, 2016w) and 16 ("Drug Suspects Arrested in Two Raids") (Lerma, 2016y) could easily be mistaken as photographs of other surrendering cohorts, but these are actually images of individuals during the more serious drug raids.

In November 2016, the PNP boasted about their accomplishment of having visited more than five million homes and having rounded up a little less than a million drug users and pushers (Bueza, 2016). But in December 2016, Senator Richard Gordon, Chair of the Senate Committee on Justice and Human Rights, revealed his committee's initial findings on the rising number of extrajudicial killings related to the all-out drug war (Elemnia 2016). One of these findings determined that the Operation Plan Tokhang violates the constitutional right of Filipinos against self-incrimination Moreover, the photographs taken by Lerma take his audience behind PNP's impressive numbers, where the thoroughness of the processing, documentation, and monitoring become questionable. Of the almost one million individuals who surrendered as of the month of November, only eight percent of them are drug pushers while the remaining percentage are users. One can only wonder how the close-to-a-million drug users who surrendered and who generally belong to the lower class, will be properly rehabilitated. The ten thousand beds of the Mega Drug Treatment and Rehabilitation Center in the province of Nueva Ecija, when it becomes fully operational, can only accommodate about one percent of them (Geronimo, 2017). In contrast, figures 18 ("After a Small Fight) (Lerma, 2016r), 19 ("At the Mess Hall") (Lerma, 2016s), and 20 ("Seagulls in Tagaytay City") (Lerma, 2016t) feature a few privileged individuals availing of the more reliable rehabilitation process from a resort-like center. Under the counterstrategies of historization and re-contextualization, all these images of Operation Plan Tokhang are putatively mobilized to question the sense and efficacy of the anti-drug strategy. And to date, the portmanteau tokhang has become synonymous with "extra-judicial killing."

\section{The State and the Nation}

Table 2 shows that the state and the nation are the least recurrent among the six sociocultural icons identified in this paper, as they are only alluded to in figures 3,17 , and 25 . This subsection of the paper tackles Lerma's most subliminal putative counter-discourse on the drug war and takes inspiration from Barthes' (1977b) essay "Rhetoric of the Image," where he explores "Italianicity" from the hues green, white, and red in a pasta advertisement 
on a French magazine (p. 34). In figure 3 ("Confessed Users Undergo a Drug Test") (Lerma, 2016h), the national colors red, blue, and yellow appear on the shirts of surrendering individuals and on the caps of the specimen containers. In figure 17 ("Nunoy was Gunned Down") (Lerma, 2016z), these colors appear again on the shirts of two policemen, on the investigation chart, on the shirt of one bystander, on the nearby car, on some posters in the background, as well as on the prints on the policemen's shirts. One of the policemen is standing directly above the inverted crucified posture of the casualty, as if the full power of the state is bearing down on the unfortunate victim. Figure 25 ("Another Killed") (Lerma, 2016q) conveys the most poetic and vivid allusion to the state as it focuses on the feet of a casualty while the moist pavement reflects the blue and red lights of a nearby police car.

Under the counterstrategy of counter-statement to the fact, the subtle allusions to the state and the nation have been putatively mobilized to contest the repeated denials of the PNP and of the Duterte administration that the state has a hand in the rising number of extrajudicial killings. Another layer of signification would be their mobilization under the same counterstrategy, that could awaken the nation into the uncomfortable realization that by cheering for the extrajudicial killings or by remaining silent about these, the whole Filipino nation could actually be sharing the responsibility for these ongoing murders.

\section{Conclusion}

Using the semiology of Barthes as framework, this paper carefully studied 25 images taken by Lerma on the still-raging drug war of the Duterte administration. From these 25 images, six sociocultural icons were identified as recurrent, namely: 1) poverty; 2) the dehumanization/ demonization of the casualties; 3) religion; 4) weakness of governance in the Philippines; 5) Operation Plan Tokhang conducted by the PNP; and 6) the state and the nation. References and allusions to these icons were mobilized under the counterstrategies of (from the most used to the least used) 1) historization and re-contextualization; 2) counter-statement to the fact; 3 ) dis-identification and normalization; 4) counter-inoculation; and 5) counter-tautology.

The reverse of the seven strategies catalogued by Barthes were used by the paper as the putative counterstrategies of Lerma's images since Barthes' strategies were supposed to be the strategies used by the dominant social groups in constructing and propagating their myths, whereas Lerma's images were supposed to be intent in contesting the myths of the ongoing drug war. In the process, this paper made a theoretical contribution by testing the capacity of Barthes's semiology to tackle not only ideological 
discourses that are tucked beneath some sociocultural icons but more so counter-ideological discourses that are launched by the less privileged sectors of society.

At the heart of this paper is the analysis of the significations in the six recurrent sociocultural icons, and following are the significations in Lerma's photographs: 1) the drug war is an anti-poor strategy; 2) the poor are also human beings and Filipinos who deserve to be treated like human beings and Filipinos; 3 ) the victims of the drug war are human beings who deserve a fair trial; 4) the victims of the drug war are not monsters; on the contrary, their humanity and their remaining traces of goodness make them deserving of the customary presumption of innocence; 5) the drug war puts to the test the self-acclaimed religiosity of the Filipinos; 6) the Filipinos' religious beliefs, like the Philippine society in general, have the tendency to favor those who belong to the upper social classes; 7) the drug problem in the Philippines may just be the tip of the iceberg of the more general problem of deficiency in strong and rational governance; 8) it is unwise for the Duterte administration to splurge its financial, political, and organizational capital on the drug war at the expense of attending to the more pressing need of strengthening and rationalizing governance; 9) there are some things that are wrong with the Operation Plan Tokhang; and 10) the state and nation are not free from any responsibility in the extrajudicial killings that are still on-going.

This paper does not claim that Lerma has full consciousness and agency in all of these significations because in Barthesian semiology, the individual propagator of a given signification may or may not be totally conscious of the full dimension of his or her signification or even of the act itself of propagating such signification. This paper, however, has reason to believe that Lerma has some consciousness and agency with respect to significations $1,2,3$, and 4 , but not necessarily regarding significations $5,6,7,8,9$, and 10. Some of Lerma's audience maybe able to sense significations $5,6,7,8$, 9 , and 10. But it is precisely the application of Barthesian semiologies on the identified sociocultural icons that reveal these otherwise concealed significations.

This paper has revealed the textual discourses hidden beneath the visual images produced by Lerma on Duterte's ongoing drug war. These textual discourses are deemed by the researcher as Lerma's take on said war. In the $\mathrm{BBC}$ video documentary, Lerma mentions that he is "for the drug war but not the killings" (Brownstone, 2016). But his stand may not be obvious in as far as the 25 selected images are concerned. Despite this, this images certainly say a lot more about the drug war and the Duterte administration. 


\section{References}

Barthes, R. (1972a). Myth today. In R. Barthes, Mythologies (pp. 109-164). New York: Noonday Press.

Barthes, R. (1972b). Photography and electoral appeal. In R. Barthes, Mythologies (pp. 91-93). New York: Noonday Press.

Barthes, R. (1972c). The great family of man. In R. Barthes, Mythologies (pp. 100-102). New York: Noonday Press.

Barthes, R. (1977a). The photographic message. In S. Heath (Ed.), Image music text (pp. 15-31). London: Fontana Press.

Barthes, R. (1977b). The rhetoric of the image. In S. Heath (Ed.), Image music text (pp. 32-51). London: Fontana Press.

Barthes, R. (1988). Shock-photos. In R. Barthes, The Eiffel Tower and other mythologies (pp.71-73). New York: Farrar, Strauss and Giroux.

Brownstone, A. (2016, Dec 04). Duterte drug war: Manila's brutal nightshift. British Broadcasting Corporation. Retrieved from https://www.bbc.com/news/av/magazine-38181753/duterte-drug-warmanila-s-brutal-nightshift

Bueza, M. (2016, Dec 24). In numbers: the Philippines"war on drugs' (32nd update). Rappler. Retrieved from https://www.rappler.com/newsbreak/iq/145814-numbers-statistics-philippines-war-drugs.

Elemnia, C. (2016, Dec 26). Draft Senate report on killings: Oplan Tokhang unconstitutional. Rappler. Retrieved from https://www.rappler.com/nation/154738-draft-senate-report-extrajudicial-killingsoplan-tokhang-unconstitutional

Esmaquel, P., II. (2016, Jul 26). Duterte hits 'Pieta' image of slain drug suspect." Rappler. Retrieved from https://www.rappler.com/nation/141008-duterte-pieta-slain-drug-suspect-inquirer

Fourth quarter 2016 Social Weather Survey: 78\% of Pinoys worry about becoming victims of EJK; $94 \%$ say it is important that drug suspects be captured alive. (2016, Dec 19). Social weather stations. Retrieved from https://www.sws.org.ph/swsmain/artcldisppage/?artcsyscode=A RT-20161219110734

Glazer, A., \& Rocklin, J. (2017, Mar 26). When a president says, 'I'll kill you'. New York Times. Retrieved from https://www.nytimes.com/by/andrew-glazer

Geronimo, J. Y. (2017, Nov 17). Dangerous Drugs Board "supports" operation of mega drug rehabitlitation in Nueva Ecija. Rappler. Retrieved from https://www.rappler.com/nation/188739-ddb-supports-mega-drug-rehabilitation-center-nueva-ecija

Gozun, B. C. \& Guillen, M.D.V. (2008). Towards a sustainable transportation environment: The case of "pedicabs" and cycling in the Philippines. The business journal. Retrieved from http://www.codatu. org/wp-content/uploads/Towards-a-sustainable-transportation-environment.-The-case-of-Pedicabs-and-cycling-in-the-Philippines-Brian-GOZUN-Marie-Danielle-GUILLEN.pdf

Gregorio, X. (2018, Oct 26). "Tokhang” named 2018 word of the year. CNN Philippines. Retrieved from https://cnnphilippines.com/news/2018/10/26/tokhang-named-2018-word-of-the-year.html International Communication Association. (2010). Code of best practices in fair use for scholarly research in communication. Center for Social Media. Retrieved from centerforsocialmedia.org/ica

Lerma, R. (2016a, Jul 04). Lamentation. Inquirer.net. Retrieved from http://newsinfo.inquirer.net/798551/ church-thou-shall-not-kill 
Lerma, R. (2016b, 20 Jul). Pray you don't see this on your street. Inquirer.net. Retrieved from http://newsinfo.inquirer.net/797360/mpd-churns-out-usual-shootout-gun-grabbing-tales-kills-7-more

Lerma, R. (2016c, Aug 06). The body of an alleged drug pusher and robber. Inquirer.net. Retrieved from http://newsinfo.inquirer.net/803494/deads-kin-offered-psychiatric-help

Lerma, R. (2016d, Aug 19). Family in anguish. Inquirer.net. Retrieved from http://newsinfo.inquirer. net/807669/killings-go-on-as-senate-probes-digong-drug-war

Lerma, R. (2016e, Aug 20). Cop killed in buy-bust operation. Inquirer.net. Retrieved from http://frame. inquirer.net/2752/cop-killed-in-buy-bust-operation/

Lerma, R. (2016f, Aug 23). Waiting to testify. Inquirer.net. Retrieved from http://frame.inquirer.net/2761/ waiting-to-testify/

Lerma, R. (2016g, Jul 06). Drug users in many parts of the country have surrendered to rehabilitation. Inquirer.net. Retrieved from http://newsinfo.inquirer.net/794564/98-drug-pushing-suspects-userssurrender-to-lanao-norte-town-cops

Lerma, R. (2016h, Jul 07). Confessed users undergo a drug test in Camp Karingal. Inquirer.net. Retrieved from http://newsinfo.inquirer.net/797445/300-qc-barangay-officers-test-positive-for-drugs

Lerma, R. (2016i, Jul 14). A drug dependent's mug shot is taken. Inquirer.net. Retrieved from http:// newsinfo.inquirer.net/797445/300-qc-barangay-officers-test-positive-for-drugs

Lerma, R. (2016j, Jul 14). Bato destroys 'bato'. Inquirer.net. Retrieved from http://newsinfo.inquirer. net/796011/drug-lords-ordered-hits

Lerma, R. (2016k, Jul 21). Policeman killed. Inquirer.net. Retrieved from http://newsinfo.inquirer. net/802212/6-killed-by-cops-in-bulacan-drug-buy-busts

Lerma, R. (2016I, Jul 21). Salvage victims. Inquirer.net. Retrieved from http://newsinfo.inquirer. net/798060/5-more-drug-war-deaths-in-12-hrs

Lerma, R. (2016m, Jul 30). Dark side of drug war. Inquirer.net. Retrieved from http://newsinfo.inquirer. net/801509/widow-tells-duterte-kill-drugs-not-people

Lerma, R. (2016n, Nov 03). Color of love. Inquirer.net. Retrieved from http://newsinfo.inquirer. net/835698/end-of-the-road-for-mayor-on-drug-list-9-others

Lerma, R. (2016o, Nov 16). A coroner cuts through the packaging tape that concealed the face of a victim of summary execution. Raffylerma.com. Retrieved from https://www.raffylerma.com/nightshift

Lerma, R. (2016p, Nov 21). Policemen keep a curious crowd . . f from a crime scene. Inquirer.net. Retrieved from http://newsinfo.inquirer.net/846158/drug-war-may-affect-kids-for-the-worse

Lerma, R. (2016q, Nov 22). Another killed. Inquirer.net. Retrieved from http://frame.inquirer.net/2960/ another-killed-2/

Lerma, R. (2016r, Oct 08). After a small fight ... these men are made to stick together. Inquirer.net. Retrieved from http://www.inquirer.net/duterte/drug-rehab-3

Lerma, R. (2016s, Oct 08). At the mess hall, an altar with religious figures watch over patients. Inquirer. net. Retrieved from http://www.inquirer.net/duterte/drug-rehab-3

Lerma, R. (2016t, Oct 08). Seagulls in Tagaytay City caters mostly to patients who can afford to pay. Inquirer.net. Retrieved from http://www.inquirer.net/duterte/drug-rehab-3 
Lerma, R. (2016u, Oct 24). Drug den raid in Quezon City. Inquirer.net. Retrieved from http://newsinfo. inquirer.net/830232/drug-suspect-with-grenade-killed-in-qc-police-raid

Lerma, R. (2016v, Oct 24). Ranilo Maydan, Jr's bullet-riddled body lies in front of his house. Inquirer.net. Retrieved from http://newsinfo.inquirer.net/830207/never-give-your-killers-peace

Lerma, R. (2016w, Sep 06). Arrested drug suspects. Inquirer.net. Retrieved from http://newsinfo.inquirer. net/813384/3-killed-15-nabbed-in-anti-drug-raid-in-pampanga-city

Lerma, R. (2016x, Sep 10). Latest four to fall. Inquirer.net. Retrieved from http://newsinfo.inquirer. net/814293/qcpds-kills-hit-72-in-du30-drug-war

Lerma, R. (2016y, Sep 18). Drug suspects arrested in two raids. Inquirer.Net. Retrieved from http://newsinfo.inquirer.net/816264/145-suspects-nabbed-in-culiat-raids

Lerma, R. (2016z, Sep 26). Nunoy [Coloma] was gunned down by still unidentified persons. Inquirer.net. Retrieved from http://newsinfo.inquirer.net/818898/103-killed-so-far-in-qcpd-war-on-drugs

Lerma, R. (n.d.). Plastic doll stained with blood, a wristwatch and a wallet that belonged to a slain 17 year old girl. Raffylerma.com. Retrieved from https://www.raffylerma.com/nightshift

Popioco, M. (2016, Jun 25). Over 700 suspected drug users, sellers surrender in Quezon City. CNN Philippines. Retrieved from https://cnnphilippines.com/news/2016/06/24/qc-drug-peddlers-surrender. $\mathrm{html}$

Regencia, T., \& Ali, M. (2016, Dec 15). Philippines: death toll in Duterte's war on drugs. Aljazeera. Retrieved from https://www.aljazeera.com/indepth/interactive/2016/08/ philippines-death-tollduterte-war-drugs-160825115400719.html.

Saussure, Ferdinand de. (1916). Cours de linguistique générale. Paris: Payot.

Southern, M. (2016, Dec 13). Google's top search ranking factors of 2016, according to Searchmetrics study. Search Engine Journal. Retrieved from https://www.searchenginejournal.com/googles-topsearch-ranking-factors-2016-according-searchmetrics-study/181157/

Wolff, J. (2015). Karl Marx. In E.N. Zalta (Ed.), Stanford encyclopedia of philosophy. Retrieved from https:// plato.stanford.edu/entries/marx/

\section{Note}

The author of this paper was able to secure the generous permission from Mr. Rafael Lerma for the use of figures 29 and 30. For figures 1 to 25, the author invokes the doctrine of fair use. In a document entitled "Code of Best Practices in Fair Use for Scholarly Research in Communication" of the International Communication Association it is stated that: "Scholars may invoke fair use to reproduce copyrighted material where it serves to explain or illustrate their scholarly insights or conclusions about communications in relation to social, cultural, political, or economic phenomena. Generally speaking, such uses transform the material reproduced by putting it in an entirely new context; thus, a music video clip used to illustrate trends in editing technique or attitudes about race and gender is being employed for a purpose entirely distinct from that of the original, and is typically directed to an entirely distinct audience from that for which it originally was intended" (2010, p. 10).

FEORILLO A. DEMETERIO III is a Full Professor of the Department of Filipino, College of Liberal Arts, and the Director of the University Research Coordination Office, De La Salle University. He served as a visiting research professor at the Council for Research in Values and Philosophy, Catholic University of America, Washington, D.C., in 2013. (Corresponding author: feorillo.demeterio@dlsu.edu.ph) 